\title{
Deregulated matriptase causes ras-independent multistage carcinogenesis and promotes ras-mediated malignant transformation
}

\author{
Karin List, ${ }^{1,4}$ Roman Szabo, ${ }^{1,4}$ Alfredo Molinolo, ${ }^{2}$ Virote Sriuranpong, ${ }^{2}$ Vivien Redeye, ${ }^{1}$ \\ Tricia Murdock, ${ }^{1}$ Beth Burke, ${ }^{1}$ Boye S. Nielsen, ${ }^{3}$ J. Silvio Gutkind, ${ }^{2}$ and Thomas H. Bugge ${ }^{1,5}$ \\ ${ }^{1}$ Proteases and Tissue Remodeling Unit, ${ }^{2}$ Molecular Carcinogenesis Unit, Oral and Pharyngeal Cancer Branch, \\ National Institute of Dental and Craniofacial Research, National Institutes of Health, Bethesda, Maryland 20892, USA; \\ ${ }^{3}$ Finsen Laboratory, Strandboulevarden 49, DK-2100, Copenhagen, Denmark
}

\begin{abstract}
Overexpression of the type II transmembrane serine protease matriptase is a highly consistent feature of human epithelial tumors. Here we show that matriptase possesses a strong oncogenic potential when unopposed by its endogenous inhibitor, HAI-1. Modest orthotopic overexpression of matriptase in the skin of transgenic mice caused spontaneous squamous cell carcinoma and dramatically potentiated carcinogen-induced tumor formation. Matriptase-induced malignant conversion was preceded by progressive interfollicular hyperplasia, dysplasia, follicular transdifferentiation, fibrosis, and dermal inflammation. Furthermore, matriptase induced activation of the pro-tumorigenic PI3K-Akt signaling pathway. This activation was frequently accompanied by H-ras or K-ras mutations in carcinogen-induced tumors, whereas matriptase-induced spontaneous carcinoma formation occurred independently of ras activation. Increasing epidermal HAI-1 expression completely negated the oncogenic effects of matriptase. The data implicate dysregulated matriptase expression in malignant epithelial transformation.
\end{abstract}

[Keywords: Transmembrane serine protease; cell surface protease; oncogenic proteolysis; carcinoma; multistage carcinogenesis; Ras]

Received January 24, 2005; revised version accepted June 13, 2005.

Matriptase (also known as MT-SP1, epithin, and TAGD$15)$ is the prototypic member of the recently identified matriptase subfamily of type II transmembrane serine proteases. This subfamily currently encompasses matriptase, matriptase-2, and matriptase-3 (Kim et al. 1999; Lin et al. 1999; Takeuchi et al. 1999; Tanimoto et al. 2001; Velasco et al. 2002; Hooper et al. 2003; NetzelArnett et al. 2003; Szabo et al. 2005). Matriptase was discovered independently as a novel cell surface protease by several investigators due to its consistent overexpression in human carcinoma. The intimate association of matriptase with human carcinoma was subsequently confirmed in a large number of studies that showed overexpression of the protease (up to several hundredfold) in a wide variety of benign and malignant tumors. The expression of matriptase was detected exclusively in tumors of epithelial origin, and not in mesenchymal-de-

\footnotetext{
${ }^{4}$ These authors contributed equally to this work.

${ }^{5}$ Corresponding author.

E-MAIL thomas.bugge@nih.gov; FAX (301) 402-0823.

Article and publication are at http://www.genesdev.org/cgi/doi/10.1101/ gad.1300705.
}

rived tumors. These included prostate, ovarian, uterine, colon, epithelial-type mesothelioma, cervical, and head and neck squamous cell carcinoma (Oberst et al. 2001, 2002; Tanimoto et al. 2001; Benaud et al. 2002; Bhatt et al. 2003; Johnson et al. 2003; Kang et al. 2003; Santin et al. 2003, 2004; Hoang et al. 2004). However, matriptase differs from most tumor-associated proteases characterized to date by being expressed exclusively by the tumor cells but not by the surrounding tumor stroma. Another important characteristic is that matriptase is expressed at every stage of carcinogenesis. Matriptase is universally coexpressed with its cognate inhibitor, hepatocyte growth factor activator inhibitor 1 (HAI-1), in both normal and malignant tissues (Oberst et al. 2001, 2002; Parr and Jiang 2001; Benaud et al. 2002; Kang et al. 2003). Recent epidemiological studies have shown that increased expression of matriptase relative to HAI-1 correlates with the grade of malignancy and predicts a poor overall survival in human breast and ovarian cancer (Oberst et al. 2002; Kang et al. 2003). Taken together, these data prompted the hypothesis that perturbation of the matriptase-HAI-1 balance promotes malignant progression. 
To directly determine the potential contribution of dysregulated matriptase expression to carcinogenesis, we manipulated the level of epidermal matriptase by transgenesis in mice. Surprisingly, we found that matriptase possesses a strong oncogenic potential. Indeed, this protease causes malignant transformation when orthotopically overexpressed even at modest levels, potently synergizes with a chemical carcinogen in a HAI-1-inhibitable manner, and supports both ras-dependent and ras-independent carcinogenesis. The data show that small perturbations of matriptase expression can initiate malignant transformation and critically potentiate the effect of genotoxic exposure, suggesting a causal role of the transmembrane serine protease in human carcinogenesis.

\section{Results}

Transgenic expression of matriptase in the epidermis of mice causes malignant transformation

To generate mice with an increased epidermal expression of matriptase, a full-length mouse matriptase cDNA was placed under the control of the bovine keratin-5 promoter and rabbit $\beta$-globin polyadenylation signals (Fig. 1A). This well-characterized expression system provides sustained transgene expression in keratin-5-expressing tissues, including the epidermis, with minimal ectopic expression (Ramirez et al. 1994). Pronuclear transgene injection of multiple zygotes gave rise to 46 weaning-age offspring, of which genomic integration of the keratin-5matriptase transgene was detected in 10 mice by Southern blot hybridization (data not shown). Four of the 10 transgenic founders were fertile but did not transmit the transgene, and another four founder animals were incapable of producing offspring (Table 1). The two remaining founders transmitted the transgene through the germline to produce two stable transgenic lines termed K5-Mat-A and K5-Mat-B. Both transgenic lines expressed the transgene in the skin as determined by transgenespecific RT-PCR (Fig. 1B). Northern blot analysis showed that the total level of matriptase mRNA was only modestly increased $(\sim 1.2$ - to 1.4 -fold $)$ in newborn skin of K5-Mat-A and K5-Mat-B transgenic mice (Fig. 1C). Real-time RT-PCR analysis established that endogenous matriptase was expressed in the skin from both newborn and adult wild-type mice with the highest level in the newborn skin (Fig. 1D). Importantly, a fivefold increase in endogenous matriptase was detected in squamous cell carcinomas from adult wild-type skin induced with DMBA combined with PMA when compared with normal untreated adult skin (Fig. 1D). This induction of endogenous matriptase is in accordance with the several previous reports describing matriptase overexpression in human carcinomas (see above). A similar expression profile for transgenic matriptase expression was seen in the skin and skin tumors of both K5-Mat-A and K5-Mat-B transgenic mice. Transgene expression was highest in newborn skin, was dramatically reduced in adult skin, and was overexpressed in squamous cell carcinoma (Fig. 1D). Furthermore, the data demonstrate sustained trans- gene expression during different stages of post-natal skin development and carcinogenesis.

In situ hybridization did not reveal pronounced alterations in the level of matriptase mRNA expression in the newborn skin (Fig. 1E). Furthermore, no obvious differences were detected in the site of expression of matriptase in transgenic and nontransgenic skin. In adult skin of keratin-5-matriptase transgenic mice, matriptase could be detected in keratinocytes by in situ hybridization (Fig. 1E), whereas the expression level of matriptase in adult wild-type skin was below the detection level of this method (data not shown). We next determined if an increased expression of keratinocyte matriptase mRNA would lead to a corresponding increase in keratinocyte matriptase protein. For this purpose, primary keratinocyte cultures were established from newborn keratin-5matriptase transgenic mice and littermate wild-type control mice. Under the culture conditions used, a robust sevenfold increase in total matriptase mRNA was observed in the transgenic keratinocytes compared with wild-type keratinocytes, as demonstrated by quantitative real-time RT-PCR (Fig. 1F) and Northern blot analysis (data not shown). Activation of the mouse matriptase on the surface of cells requires an initial endoproteolytic cleavage of the zymogen within the SEA domain, which leads to the shedding of the activated protease from the cell surface as an $\sim 92-k D a$ protein (Cho et al. 2001). We determined the levels of soluble matriptase shed into the conditioned medium of keratin-5-matriptase keratinocytes and littermate wild-type keratinocytes, using a gelatin zymography procedure that was recently established for the selective detection of human matriptase in conditioned medium of cultured human tumor cells (Jin et al. 2005). Using this assay, matriptase was detected as an $\sim 90-k D a$ gelatinolytic activity (Fig. 1G) that displayed an increase in intensity in the conditioned medium from keratin-5-matriptase transgenic keratinocytes that was compatible with the marked increase in total matriptase mRNA in the transgenic keratinocytes (Fig. 1G,H). Several lower-molecular-weight gelatinolytic activities that were inhibited by a generic serine protease inhibitor (data not shown) were also markedly increased in the conditioned medium from keratin-5-matriptase transgenic keratinocytes (Fig. 1G). These activities may represent additional enzymatically active matriptase proteolytic processing products analogous to those described for human matriptase (Lin et al. 1997; Jin et al. 2005), or they may be representing different keratinocyte serine proteases whose abundance or activity is increased in response to matriptase overexpression. Taken together, these data show a modest and sustained increase in total keratinocyte matriptase in keratin-5 matriptase transgenic mice. The low frequency of founder generation, founder fertility, and germline transmission, as well as the modest level of overexpression of the transgene indicate that increased expression of matriptase impedes embryonic or neonatal life and mouse fertility. When combined with our previous studies showing severe developmental defects and perinatal lethality in matriptase-deficient mice (List et al. 2002, 2003), the 
List et al.

Figure 1. Generation of keratin-5-matriptase transgenic mice. (A) Schematic structure of the keratin-5-matriptase transgene. The bovine keratin-5 promoter (K5), rabbit $\beta$-globin exons $(E)$, rabbit $\beta$-globin intron $B$, mouse matriptase cDNA, rabbit $\beta$-globin polyadenylation signal (Poly A), and positions of primers used for mouse genotyping ( $\mathrm{a}$ and $\mathrm{b}$ ) and RT-PCR analysis (c and d) of transgene-specific matriptase mRNA are indicated. $(B)$ Expression of the keratin-5-matriptase transgene in mouse skin. RT-PCR analysis of skin from wild type (lanes 1,3), littermate keratin-5-matriptase transgene-line-A (K5-Mat-A) (lane 2), and keratin-5-matriptase transgeneline-B (K5-Mat-B) (lane 4) using a transgene-specific primer pair as indicated in $A$, or a primer pair amplifying GAPDH mRNA. The positions of DNA fragments amplified from the transgene-derived matriptase mRNA (188 bp), and GAPDH (236 bp) are indicated with arrows. $(C)$ Northern blot analysis of total matriptase mRNA in the skin of newborn wild-type and keratin-5-matriptase transgenic mice. The ratio of matriptase to GAPDH signal intensity is shown. $(D)$ Quantitative realtime PCR analysis of relative endogenous matriptase mRNA expression in wild-type newborn skin, adult skin (4 mo), and DMBA/PMA-induced tumors (left panel), and relative transgenic matriptase mRNA expression in K5-Mat-A (middle panel) and K5-Mat-B (right panel) transgenic mice. The matriptase expression levels were normalized to GAPDH mRNA expression. (E) In situ hybridization of matriptase mRNA expression in newborn skin of wild-type and littermate K5-Mat-A transgenic mice (left panels), newborn wild-type and littermate K5-Mat-B transgenic mice (middle panels), and adult hyperplastic skin (1 yr old) from a K5-Mat-B-transgenic mouse (right panel) using ${ }^{35} \mathrm{~S}-\mathrm{labeled}$ antisense probes and sense probes as indicated. Identical results were obtained with two nonoverlapping pairs of antisense and sense probes. $(F)$ Quantitative real-time PCR analysis of total matriptase mRNA expression in primary cultured keratinocytes from K5Mat-B and littermate wild-type mice. The matriptase expression levels were normalized to expression of GAPDH mRNA. (G) Matriptase gelatin zymography of concentrated conditioned media from cultured keratinocytes from three newborn wild-type pups (lanes 1-3) and three littermate K5-matriptase pups (lanes 4-6). The bracket indicates zones of gelatin lysis. (H) Optical scanning of the clarity of the $90-\mathrm{kDa}$ lysis zones in $G$. (I) Coomassie-stained gel containing the samples used for matriptase gelatin zymography in $G$ analyzed in parallel by SDS-PAGE to verify equal protein loading. $(G, I)$ Molecular weight markers (in kilodaltons) are indicated on the left. (Arrowheads) Follicles; (arrows) interfollicular epidermis; $N$ indicates the number of mice analyzed; error bars indicate standard error of the mean. Scale bars, $100 \mu \mathrm{m}$.

data suggest that mouse epidermis is sensitive to both increased and decreased levels of matriptase.

K5-Mat-A transgenic mice at 1 yr of age developed distinct proliferative skin lesions (Fig. 2A). These lesions were observed in $100 \%$ of the transgenic mice (10/10) followed for 12-23 mo, whereas no skin lesions were observed in 11 matched wild-type control mice observed

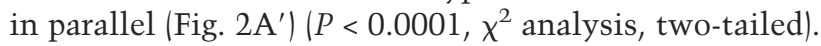
The keratin-5-matriptase transgenic mice were monitored closely until their lesions interfered with animal welfare, and were then subjected to a detailed histo- pathological analysis (Fig. 2C-G; Table 2). Surprisingly, all lesions were revealed to be epidermal neoplasias (Fig. $2 \mathrm{~B}$; Table 2). Moreover, seven of 10 lesions (70\%) presented as carcinomas that varied from moderately differentiated squamous cell carcinoma (Fig. 2C) to poorly differentiated squamous cell carcinoma with spindleshaped areas (Fig. 2D). The spindle-shaped areas were of epithelial origin, as they expressed cytokeratins and Ecadherin, but not the mesenchymal marker vimentin (Fig. 2E). At euthanization, all the squamous cell carcinomas had invaded the underlying dermis, adipose tis- 
Table 1. Generation of keratin-5-matriptase transgenic mice

\begin{tabular}{lclccc}
\hline Transgenic founder & Skin phenotype & Gender & Fertile & Transgene transmission & F $_{1}$ skin phenotype \\
\hline FVB-K5-Mat-A & No & Male & Yes & Yes & Yes \\
FVB-K5-Mat-B & Yes & Female & Yes & Yes & No \\
FVB-K5-Mat-C & No & Female & Yes & No & - \\
FVB-K5-Mat-D & No & Female & Yes & No & - \\
FVB-K5-Mat-E & No & Male & Yes & No & - \\
FVB-K5-Mat-F & No & Female & Yes & - & - \\
FVB-K5-Mat-G & Yes & Female & No & - & - \\
FVB-K5-Mat-H & No & Male & No & - & - \\
FVB-K5-Mat-I & Yes & Male & No & - & - \\
FVB-K5-Mat-J & Yes & Male & No & & - \\
\hline
\end{tabular}

Transgenic founders were identified by Southern blot hybridization of 46 offspring of zygotes with pronuclear transgene injection. Skin phenotype included hyperproliferative interfollicular epidermal hyperplasia, follicular transdifferentiation, alopecia, dermal fibrosis, and dermal inflammation. Fertility was established by repeated mating to FVB mice.

sue, and muscle, and occasionally even deeper lying tissues such as the mammary gland (Fig. 2F,G; Table 2). Adult mice from both transgenic lines developed dermatitis of the ears, with more severe lesions observed in K5-Mat-B mice, which necessitated euthanization of this transgenic line prior to entering middle age. Therefore, only a few K5-Mat-B mice could be monitored beyond 12 mo of age. However, comparison of age-matched K5Mat-A and K5-Mat-B mice revealed a similar spectrum of premalignant epidermal changes, including multifocal dysplasia, in both transgenic lines (see below). Taken together, the data unexpectedly show that modest orthotopic epidermal overexpression of matriptase in mice suffices to drive the full spectrum of malignant conversion from normal epithelium to invasive squamous cell carcinoma.

\section{Matriptase strongly potentiates chemical carcinogenesis}

Human carcinogenesis is a multistage process that frequently involves exposure to environmental genotoxins. We next assessed the effect of increased matriptase expression on epithelia subjected to genotoxic stress. To this end, the skin of K5-Mat-B mice and wild-type littermate control mice was exposed to three different doses of 7,12-dimethylbenzanthracene (DMBA). This wellstudied carcinogen has been shown in previous studies to cause skin tumor formation in FVB mice, either when applied repeatedly to the skin, or when applied in combination with the tumor promoter phorbol 12-myristate 13-acetate (PMA) (Hennings et al. 1993). In agreement with previous studies, a single application of DMBA to
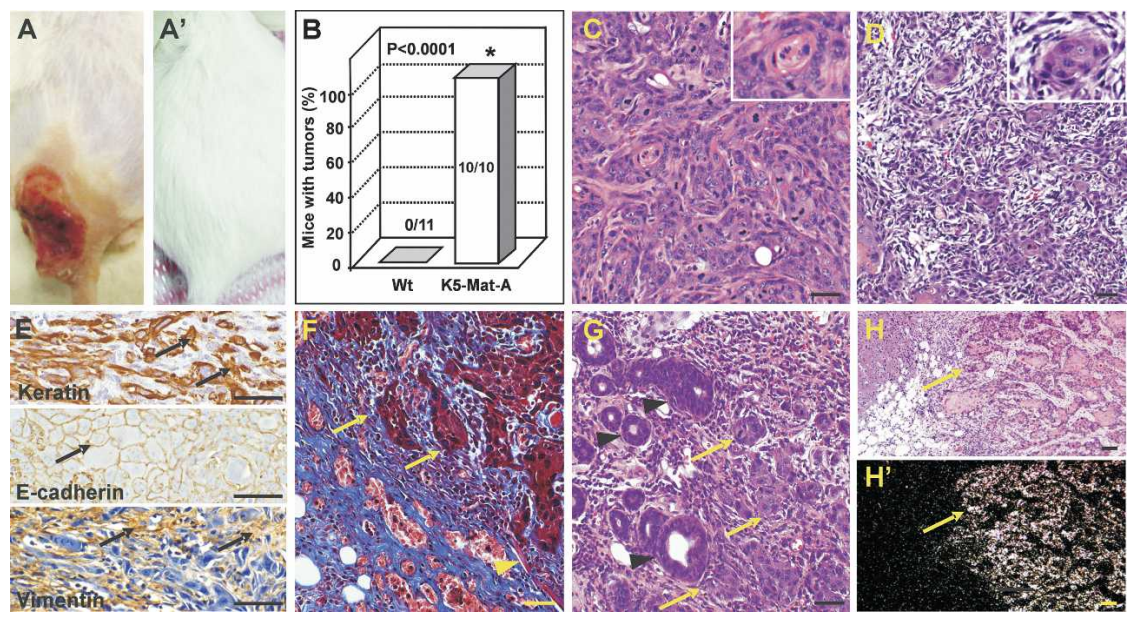

Figure 2. Matriptase overexpression causes malignant transformation of mouse epidermis. (A) Squamous cell carcinoma at the base of the tail with ulceration, invasion, and erosion of adjacent tissues in a 12-mo-old keratin-5-matriptase transgenic mouse. $\left(A^{\prime}\right)$ A wild-type control mouse at 12 mo of age is shown for comparison. (B) Frequency of epidermal tumors in wildtype (gray bar) and K5-Mat-A transgenic mice (white bar) at 12-23 mo of age, as assessed by histopathological analysis. The $P$ value was determined by $\chi^{2}$ analysis, two-tailed. $(C, D)$ Representative examples of the histological appearance of moderately differentiated keratinizing squamous cell carcinomas $(C)$ and a poorly differentiated squamous cell carcinoma with spindle-shaped areas without obvious squamous differentiation $(D)$ arising spontaneously in 13- and 21-mo-old keratin-5matriptase transgenic mice, respectively. Insets show cytological features of the tumors at high magnification. $(E)$ The spindle-shaped tumor cells express keratin (top panel, examples with arrows) and E-cadherin (middle panel, examples with arrows), whereas vimentin expression is restricted to the stromal compartment (lower panel, examples with arrows), demonstrating the epithelial origin of the tumors. (F) Invasion of dermal connective tissue (blue) and dermal muscle (arrow-heads) by squamous cell carcinoma (arrows) from a 13-mo-old K5-Mat-A mouse. $(G)$ Infiltration of mammary gland by matriptase-induced carcinoma (arrows) with destruction of mammary ducts (arrowheads). Bright-field $(H)$ and dark-field $\left(H^{\prime}\right)$ in situ hybridization of squamous cell carcinoma from a 13-mo-old mouse show expression of matriptase by tumor cells (arrows). $(C, D, G, H)$ Hematoxylin and eosin staining. (E) Immunohistochemical staining using pan-keratin, E-cadherin, and vimentin antibodies, respectively. (F) Masson's trichrome staining. Scale bars, $100 \mu \mathrm{m}$. 
List et al.

Table 2. Spontaneous epidermal tumor development in FVB keratin-5-matriptase mice

\begin{tabular}{|c|c|c|c|}
\hline Mouse & Gender & $\begin{array}{l}\text { Age at analysis } \\
\text { (months) }\end{array}$ & Diagnosis of skin lesions \\
\hline FVB-K5-Mat-A-1 & Male & 12 & Epidermal papilloma with dermal inflammation. \\
\hline FVB-K5-Mat-A-2 & Male & 12 & $\begin{array}{l}\text { Moderately differentiated ulcerative squamous cell carcinoma with focal } \\
\text { anaplasia lacking obvious squamous differentiation. Dermal and subdermal } \\
\text { invasion with infiltration and destruction of adipose and muscle tissue. }\end{array}$ \\
\hline FVB-K5-Mat-A-3 & Male & 13 & Epidermal papilloma, dysplasia, and dermal inflammation. \\
\hline FVB-K5-Mat-A-4 & Female & 13 & $\begin{array}{l}\text { Moderately differentiated ulcerative squamous cell carcinoma. Dermal and } \\
\text { subdermal invasion with destructioin of adipose and muscle tissue. } \\
\text { Diffuse infiltration of mammary gland. }\end{array}$ \\
\hline FVB-K5-Mat-A-5 & Male & 14 & Epidermal papilloma, dysplasia, and dermal inflammation. \\
\hline FVB-K5-Mat-A-6 & Female & 15 & $\begin{array}{l}\text { Moderately differentiated ulcerative squamous cell carcinoma. Dermal and } \\
\text { subdermal invasion with destruction of adipose and muscle tissue. }\end{array}$ \\
\hline FVB-K5-Mat-A-7 & Female & 19 & Squamous cell carcinoma with dermal invasion. \\
\hline FVB-K5-Mat-A-8 & Male & 21 & $\begin{array}{l}\text { Ulcerative squamous cell carcinoma. Biphasic with zones of } \\
\text { well-differentiated squamous cell carcinoma mixed with zones of } \\
\text { spindle-shaped carcinoma. Infiltration of muscle and adipose tissue. }\end{array}$ \\
\hline FVB-K5-Mat-A-9 & Female & 23 & $\begin{array}{l}\text { Ulcerative squamous cell carcinoma. Biphasic with zones of moderately } \\
\text { differentiated squamous cell carcinoma mixed with zones of } \\
\text { spindle-shaped carcinoma. Infiltration and destruction of muscle and } \\
\text { adipose tissue. }\end{array}$ \\
\hline FVB-K5-Mat-A-10 & Female & 23 & $\begin{array}{l}\text { Moderately differentiated ulcerative squamous cell carcinoma. Dermal } \\
\text { invasion reaching panniculus muscle. }\end{array}$ \\
\hline
\end{tabular}

No epidermal tumors were found in age-matched wild-type FVB control mice.

the skin of wild-type mice did not cause significant tumor formation, with just $1.7 \%(1 / 59)$ of wild-type mice in all study cohorts presenting with a papilloma (Fig. $3 \mathrm{~A}, \mathrm{~B})$. In striking contrast, however, $95 \%$ (38/40) of littermate keratin-5-matriptase transgenic mice developed tumors within 40 wk after DMBA exposure, beginning at $7 \mathrm{wk}$ after treatment. Even a single topical application of as little as $2 \mu \mathrm{g}$ of DMBA to matriptase-overexpressing skin sufficed to cause tumors in $62 \%(8 / 13)$ of mice 20 75 wk after DMBA exposure (Fig. 3A,B). The DMBAinduced tumors in keratin-5-matriptase transgenic mice displayed a very high frequency of malignant conversion, with squamous cell carcinoma presenting in $42 \%, 68 \%$, and $38 \%$ of mice treated with 100,25 , and $2 \mu \mathrm{g}$ of DMBA, respectively (Fig. 3B). The matriptase/DMBA-induced carcinomas presented as well-differentiated to moderately differentiated squamous cell carcinomas (Fig. 3C,D) that expressed matriptase in the epithelial compartment as shown by in situ hybridization (Fig. 3E), with a pattern of expression that was qualitatively similar to tumors induced in wild-type mice by combined DMBA/PMA treatment (Fig. 4D, top panel). The matriptase/DMBA-induced carcinomas all invaded the underlying tissues, eroding the dermis, adipose tissue, and muscle (Fig. 3F). Metastasis to draining lymph nodes (Fig. 3G) and, occasionally, to distant organs (Fig. 3H) was observed in $25 \%(6 / 24)$ of carcinoma-bearing mice at 33-40 wk. Taken together, the data show that matriptase dramatically enhances the potency of DMBA. Indeed, the reported threshold for tumor formation in wild-type FVB mice after DMBA exposure (Hennings et al. 1993) is $>100$-fold higher than that established here for keratin5-matriptase transgenic mice (20 weekly applications of $10 \mu \mathrm{g}$ DMBA in FVB mice vs. one application of $2 \mu \mathrm{g}$ of
DMBA in FVB-keratin-5-matriptase transgenic mice). In conclusion, the data show that matriptase overexpression makes carcinogen-exposed epithelium extremely sensitive to malignant transformation. This suggests that the matriptase expression level in an epithelium may be a critical determinant of the pathological consequences of genotoxic exposure.

\section{The effects of increased matriptase during $D M B A$-induced carcinogenesis emulate the effects of constitutive PKC and PI3K activation}

Repeated applications of PMA and related tumor promoters induce tumor formation in DMBA-exposed mouse skin through the constitutive activation of the protein kinase $\mathrm{C}$ pathway in keratinoctyes carrying DMBA-induced ras mutations (Quintanilla et al. 1986; Yuspa 1998). To determine if matriptase overexpression synergizes with or functionally equates this tumor promoter, cohorts of keratin-5-matriptase transgenic mice and wild-type littermate control mice were treated with $25 \mu \mathrm{g}$ of DMBA followed by biweekly applications of 12 $\mu \mathrm{g}$ of PMA. As reported previously (Hennings et al. 1993), this treatment induced benign tumors (papillomas) in wild-type FVB mice, with all mice presenting with papillomas 12 wk after DMBA initiation (Fig. $4 \mathrm{~A}, \mathrm{C})$. Interestingly, however, using this treatment protocol, increased epidermal expression of matriptase did not accelerate papilloma formation (Fig. 4A), or significantly increase the rate of conversion of papillomas to squamous cell carcinoma, as determined by histopathological analysis 12 wk after initiation of DMBA/PMA treatment (Fig. 4C). Furthermore, matriptase did not increase the rate of tumor formation in mice treated with 
A

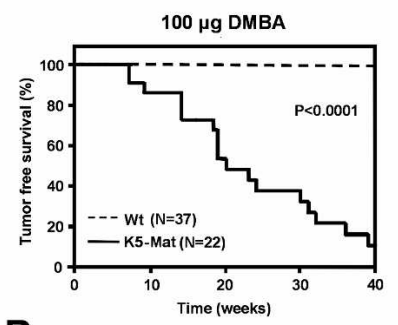

B
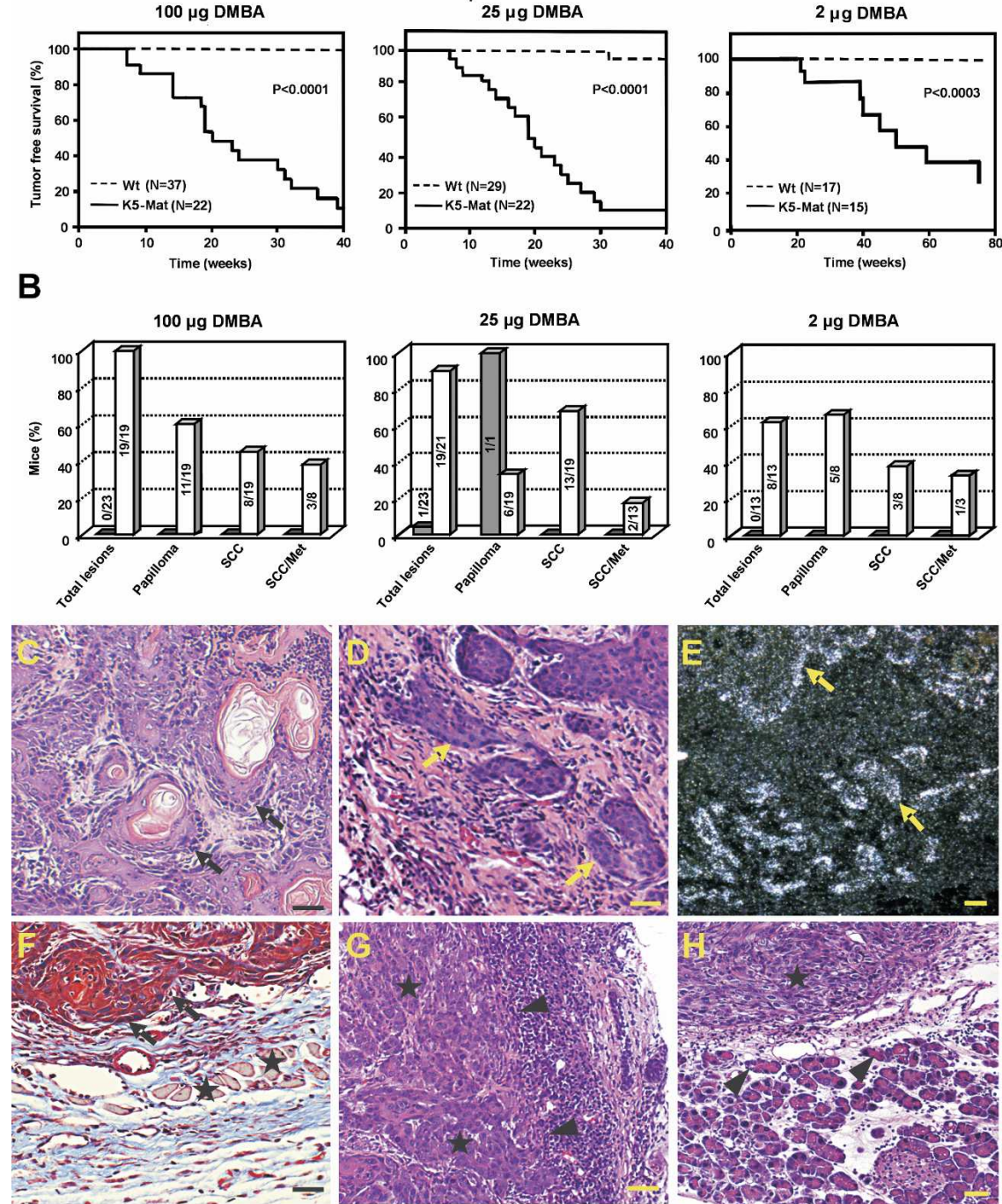

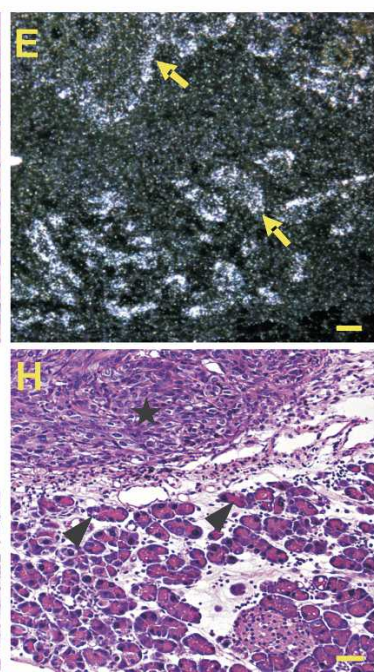

Figure 3. Matriptase is a strong potentiator of chemical carcinogenesis. (A) KaplanMeier analysis of epidermal tumor formation in keratin-5-matriptase transgenic mice and wild-type littermate control mice after a single topical application of $100 \mu \mathrm{g}$ (left panel), $25 \mu \mathrm{g}$ (middle panel), and $2 \mu \mathrm{g}$ (right panel) of DMBA in acetone to the lumbar region of the dorsal back skin. $N$ indicates the number of keratin-5matriptase and wild-type littermate control mice initially enrolled in each study cohort. $P$ values were determined by the log-rank test, two-tailed. Untreated wildtype mice or keratin-5-matriptase transgenic mice did not develop tumors within the observation period. (B) Frequency of total neoplastic lesions (Total lesions), Papillomas, squamous cell carcinoma (SCC), and metastatic squamous cell carcinoma (SCC/Met) in wild-type (gray bars) and littermate keratin-5-matriptase (white bars) mice after treatment with $100 \mu \mathrm{g}$ (left panel), $25 \mu \mathrm{g}$ (middle panel), and $2 \mu \mathrm{g}$ (right panel) of DMBA. Lesions were assessed histologically 20-40 wk after DMBA treatment. Numbers within or above bars indicate number of mice with tumors. $(C, D)$ Representative examples of the histological appearance at high magnification of well-differentiated squamous cell carcinoma $(C)$ and moderately differentiated squamous cell carcinoma $(D)$ in K5-Mat-B transgenic mice 40 wk after treatment with $25 \mu \mathrm{g}$ of DMBA. Examples of tumor cells are indicated with arrows. (E) In situ hybridization showing matriptase expression in the epithelial compartment of matriptase/DMBA-induced tumors (examples with arrows). (F) Carcinoma invasion (arrows) of dermal connective tissue (blue) and dermal muscle (stars). (G) Metastatic squamous cell carcinoma mass (stars) in lymph node with effacement of lymphoid tissue (arrowheads). $(H)$ Metastatic mass (star) of the pancreas surplanting pancreatic tissue (arrowheads). $(C, D, G, H)$ Hematoxylin and eosin staining. (F) Masson's trichrome staining. Scale bars, $100 \mu \mathrm{m}$.

PMA in the absence of DMBA initiation (Fig. 4B). Both DMBA/PMA-induced tumors in wild-type mice and DMBA-induced tumors in keratin-5-matriptase transgenic mice expressed matriptase in the epithelial compartment (Fig. 4D).

Several components of the phosphatidylinositol 3-kinase (PI3K)-Akt pathway are dysregulated in a wide spectrum of human cancers including human squamous cell carcinoma (Vivanco and Sawyers 2002; Amornphimoltham et al. 2004), and recent studies have demonstrated increased Akt activity in mouse skin during the PMA-induced promotion stages of chemical carcinogenesis (Segrelles et al. 2002). Interestingly, immunohistochemical analysis of skin from untreated keratin-5-matriptase transgenic mice showed increased epidermal expression of activated Akt (Fig. 4E) and PDK1 (data not shown). Taken together, the data show that the onco- genic pathway(s) that is activated by matriptase overexpression does not functionally synergize with the tumor promoter PMA. Furthermore, matriptase overexpression causes activation of the tumor-promoting PI3K-Akt pathway. This suggests that dysregulated matriptase and sustained PMA exposure may cause activation of functionally similar cellular signaling pathways to induce and promote carcinogenesis in squamous epithelium.

\section{Epidermal dysplasia, follicular transdifferentiation, fibrosis, and dermal inflammation precede tumor formation in keratin-5-matriptase transgenic mice}

The epidermis of both K5-Mat-A and K5-Mat-B transgenic mice was subjected to a detailed analysis to understand the events that precede matriptase-induced squamous cell carcinogenesis (Fig. 5; data not shown). The 
Figure 4. Tumor promotion by matriptase emulates PKC and PI-3K activation. $(A, B)$ Analysis of epidermal tumor formation in K5-Mat-B transgenic mice and wild-type littermate control mice after a single topical application of $25 \mu \mathrm{g}$ of DMBA to the lumbar region of the dorsal back skin followed by biweekly applications of PMA $(A)$ or biweekly PMA treatment without DMBA initiation $(B) . \quad P=$ N.S., log-rank test, twotailed. (C) Frequency of total neoplastic lesions (Total lesions), Papillomas, and squamous cell carcinoma (SCC) in wildtype (gray bars) and K5-Mat-B mice (white bars), assessed by histopathological analysis of tumors 12 wk after the initiation of DMBA/PMA treatment. Numbers within bars indicate number of mice with tumors. $P=$ N.S., $\chi^{2}$ test, two-tailed. (D) Dark-field micrograph of in situ hybridizations showing expression of matriptase in the tumor cells (arrows) of both DMBA/PMA-treated wild-type (top panel) and DMBA-treated littermate K5-Mat-B transgenic mice (bottom panel). (E) Phospho-Akt immunostaining of chemically nontreated adult skin from a wild-type mouse (top panel) with few positive cells scattered in the epidermis and a K5-Mat-transgenic mouse (bottom panel) with increased intensity and number of positive cells for phospho-Akt (examples indicated with arrows). Scale bars, $50 \mu \mathrm{m}$.

skin of keratin-5-matriptase transgenic mice was unremarkable at birth (Fig. 5A). However, beginning at $\sim 3 \mathrm{wk}$ of age, similar progressive abnormalities were observed in the interfollicular epidermis, the follicular epidermis, and the dermis of both keratin-5-matriptase transgenic mouse lines. Interfollicular epidermal hyperplasia was detectable at weaning (Fig. 5B), was severe at 5 mo of age (Fig. 5C), and progressed to multifocal dysplasia consistent with carcinoma in situ when examined at 10 mo of age (Fig. 5D). The severe epidermal hyperplasia was caused by a dramatic increase in the number of proliferating transit amplifying cells within the interfollicular epidermis, which exceeded fivefold at 3 mo of age (Fig. $5 \mathrm{E}, \mathrm{F})$. The interfollicular epidermal hyperproliferation was associated with expression of the stress-associated marker keratin-6 (Fig. 5H), and with the activation of the tumor-promoting PI3K-Akt signaling pathway (Fig. 4E; data not shown), but not with impaired terminal epidermal differentiation, as determined by the expression of suprabasal keratins-1 and -10 and the transitional layer/ stratum corneum markers loricrin and filaggrin (data not shown). Interestingly, however, overexpression of matriptase did not affect the proliferative capacity or survival of transgenic keratinocytes when cultured in vitro under a variety of growth conditions (Fig. 5G; data not shown) (see Discussion).

The follicular epidermis of keratin-5-matriptase transgenic mice gradually underwent a complete transdifferentiation to become interfollicular epidermis, as shown by the de novo expression of the interfollicular epidermis-specific markers keratin-1 (Fig. 5I) and loricrin (Fig. $5 \mathrm{~J})$ in the hair follicles. This transdifferentiation was accompanied by the fusion of the follicular epidermis to the interfollicular epidermis (Fig. 5K), leading to loss of hair follicles and varying degrees of alopecia in mice at early middle age (example in Fig. 9A, below).

Fibrosis was uniformly observed in the dermis underlying hyperplastic and dysplastic areas of matriptase transgenic skin, associated with markedly increased collagen deposition and hypercellularity of both dense and loose dermal connective tissue (Fig. 5L). Persistent dermal inflammation with large increases in F4/80-positive macrophages and toluidine blue-staining mast cells accompanied the dermal fibrotic response to matriptase overexpression (Fig. 5M,N). In addition to the two established lines K5-Mat-A and K5-Mat-B, very similar skin phenotypes were observed in three independent transgenic founders that did not transmit the transgene to offspring (K5-Mat-G, K5-Mat-I, and K5-Mat-J) (Table 1), which makes insertional effects of the transgene an implausible cause of the observed effects.

\section{Matriptase promotes both ras-dependent and -independent carcinogenesis}

A genetic analysis of tumors was undertaken to determine the molecular events that underlie matriptase-induced carcinogenesis. DMBA and related carcinogens, when applied in combination with PMA to mouse skin, predominantly give rise to epidermal tumors with activating mutations in ras (Balmain and Pragnell 1983; Balmain 1985; Quintanilla et al. 1986; Ise et al. 2000). In agreement with this, all examined DMBA/PMA-induced tumors in wild-type mice (6/6) displayed activating mutations either in H-ras or K-ras when analyzed by direct sequencing and by restriction enzyme digestion analysis 

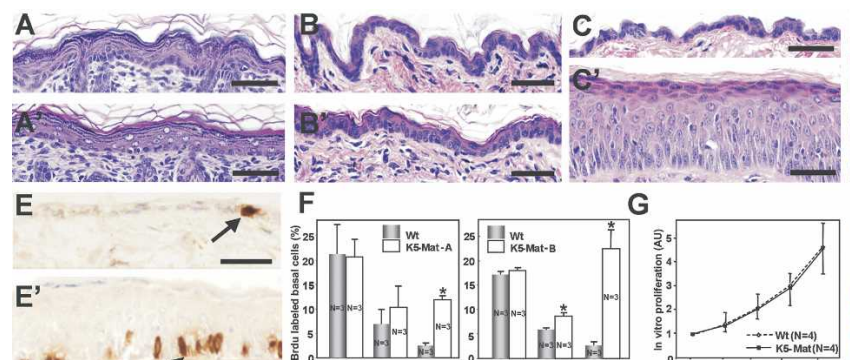

$\mathbf{G}$
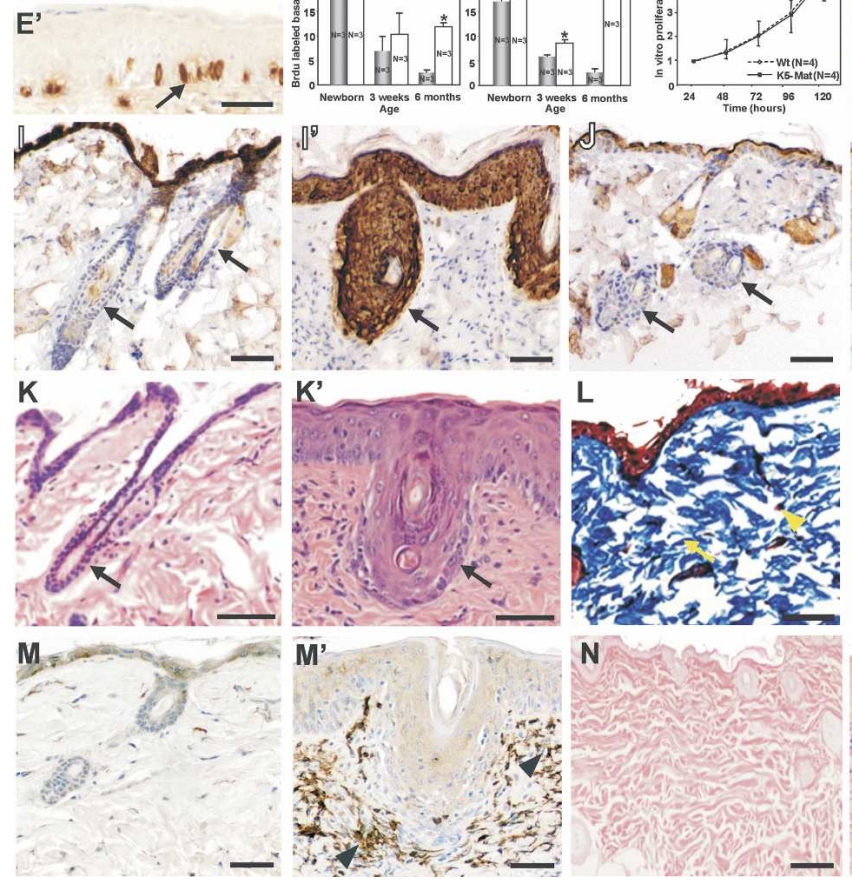
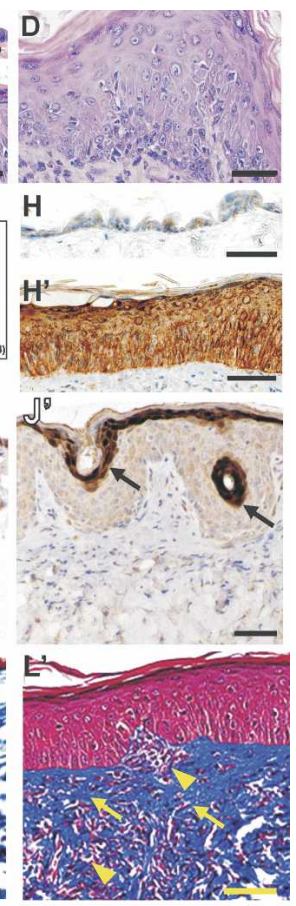

N'

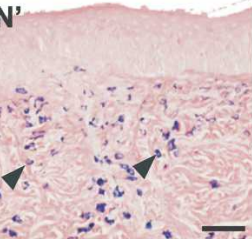

Figure 5. Matriptase-induced multistage carcinogenesis. $(A-E)$ Interfollicular epidermal hyperplasia progressing to dysplasia in keratin-5-matriptase transgenic mice. Histological appearance of the interfollicular epidermis of wild-type $(A)$ and K5-Mat-B $\left(A^{\prime}\right)$ mice at birth, $3 \mathrm{wk}$ of age $\left(B, B^{\prime}\right)$, and 5 mo of age $\left(C, C^{\prime}\right)$, showing normal interfollicular epidermis at birth and epidermal hyperplasia in young adult keratin-5matriptase transgenic mice. $(D)$ Representative example of the epidermis of 10-moold K5-Mat-B mice showing severe epidermal dysplasia in middle-aged keratin-5-matriptase transgenic mice. BrdU pulse labeling of interfollicular epidermis from 5-mo-old wild-type $(E)$ and K5-Mat-B $\left(E^{\prime} ;\right)$ mice. BrdU incorporation analysis showing an increased number of basal keratinocytes (examples with arrows) in keratin-5-matriptase transgenic interfollicular epidermis. (F) Proliferation indices of basal keratinocytes in the epidermis of newborn, weaning-age, and 5-mo-old wild-type K5-Mat-A mice (gray bars) and littermate wild-type mice (white bars) (left panel), and newborn, weaning-age, and 3-mo-old wild-type mice (white bars) and K5-Mat-B mice (gray bars) (right panel). Mice were injected with BrdU $2 \mathrm{~h}$ before euthanization, and the fraction of BrdU-incorporating basal keratinocytes was determined with BrdU antibodies. $\left(^{*}\right) P<0.001$, Student's $t$-test, twotailed. (G) Proliferation of wild-type and keratin-5-matriptase transgenic keratinocytes in culture ( $N$ is the number of independent cultures analyzed, and AU indicates arbitrary units). Error bars indicate standard deviation. $P=$ N.S., Student's $t$-test, two-tailed. $(H)$ Expression of the hyperproliferation-associated marker keratin-6 in the interfollicular epidermis of keratin-5-matriptase transgenic mice $\left(H^{\prime}\right)$ but not in wild-type littermate mice $(H)$. $(I-K)$ Follicular to interfollicular transdifferentiation in keratin-5-matriptase transgenic mice. Expression of interfollicular epidermisspecific keratin-1 $\left(I^{\prime}\right)$ and loricrin $\left(J^{\prime}\right)$ in enlarged hair follicles (arrows) of 5-mo-old keratin-5-matriptase transgenic mice, but not in wild-type littermate mice $(I, J)$. Gross enlargement, complete interfollicular transdifferentiation, and fusion of hair follicles with interfollicular epidermis in 5-mo-old K5-Mat-B transgenic mouse $\left(K^{\prime}\right)$ compared with littermate wild-type mouse $(K)$. Profound dermal fibrosis with hypercellularity (cf. $L$ and $L^{\prime}$, examples with arrowheads) and increased collagen deposition (cf. $L$ and $L^{\prime}$, examples with arrows) and accumulation of F4/80-positive macrophages $\left(M^{\prime}\right.$, examples with arrowheads) and toluidine blue-positive mast cells $\left(N^{\prime}\right.$, examples with arrowheads) in 5-mo-old K5-Mat-B transgenic mice compared with wild-type littermate mice $(L, M, N$, respectively). $(A-D, K)$ Hematoxylin and eosin staining. $(E-J, M)$ Immunohistochemical staining with BrdU, keratin-6, keratin-1, loricrin, and F4/80 antibodies, respectively. (L) Masson's trichrome staining. $(N)$ Toluidine blue/eosin staining. Scale bars, $50 \mu \mathrm{m}$.

(Fig. 6; Table 3). Activating ras mutations were also found in $75 \%(12 / 16)$ of tumors from DMBA-treated keratin-5-matriptase transgenic mice (Fig. 6; Table 3). The very high frequency of activating ras mutations in DMBA/matriptase-induced tumors shows that matriptase promotes malignant transformation of keratinocytes with DMBA-induced activation of ras, or, conversely, promotes the accumulation of keratinocytes with activating ras mutations in DMBA-treated skin, thus demonstrating a strong functional cooperativity between the cell surface protease and ras oncoproteins. Interestingly, however, an exhaustive analysis of seven tumors developing spontaneously in middle-aged nonDMBA-treated keratin-5-matriptase transgenic mice that included both the codon 12-13 region and the codon 59-61 region of $\mathrm{H}$-ras and K-ras and used both direct sequencing and restriction enzyme digestion analysis revealed the uniform absence of activating ras mutations (Fig. 6; Table 3). Taken together, this analysis shows that matriptase promotes both ras-dependent and ras-independent carcinogenesis, suggesting a versatile pro-tumorigenic effect of dysregulated expression of the novel carcinoma-associated transmembrane serine protease.

\section{Epidermal HAI-1 overexpression negates the oncogenic effects of matriptase}

The effect of increasing the epidermal expression of the matriptase inhibitor HAI-1 on matriptase-induced tumorigenesis was investigated next to determine if the strong oncogenic potential of matriptase could be counteracted by the specific inhibition of matriptase. To this 
List et al.

Figure 6. Matriptase promotes squamous cell carcinogenesis both dependent and independent of ras activation. Representative examples of restriction enzyme digest analysis of codon $61(A)$, and sequencing analysis of codon 59-61 region and codon 12-13 region (B) of H-ras (left panels) and $\mathrm{K}$-ras (right panels) of spontaneous squamous cell carcinomas in keratin-5-matriptase transgenic mice (lane 1), squamous cell carcinomas in DMBA/PMA-treated keratin-5-matriptase transgenic mice (lane 2), DMBA/PMA-induced squamous cell carcinomas in wild-type mice (lane 3), and DMBA-induced squamous cell carcinomas in keratin-5-matriptase transgenic mice (lane 4). DNA was amplified by PCR and subjected to restriction digest with $\mathrm{XbaI}$, which detects the presence of activating A-to- $T$ transitions (CAA to CTA) in codon 61 of $\mathrm{H}$-ras and $\mathrm{K}$-ras $(A)$, and sequencing of the generated PCR product either directly or after cloning of the PCR product into a plasmid vector $(B)$.
A
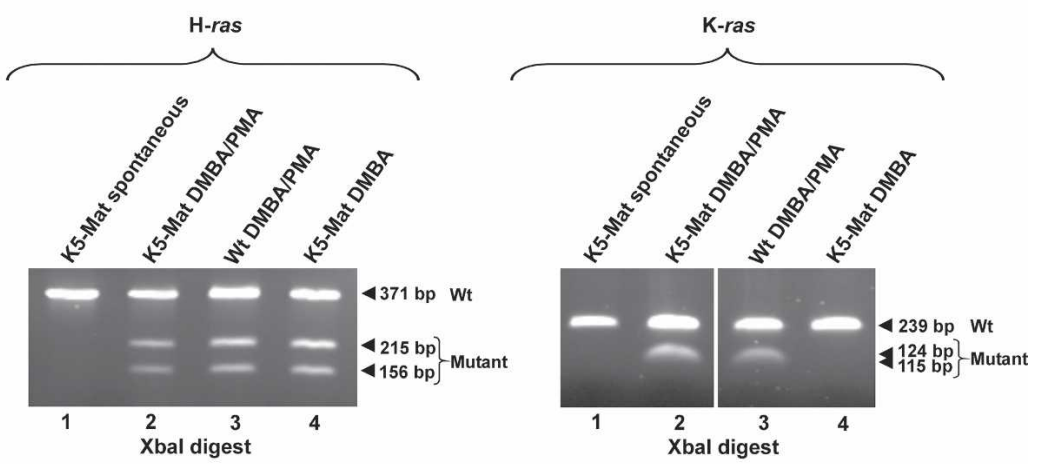

B
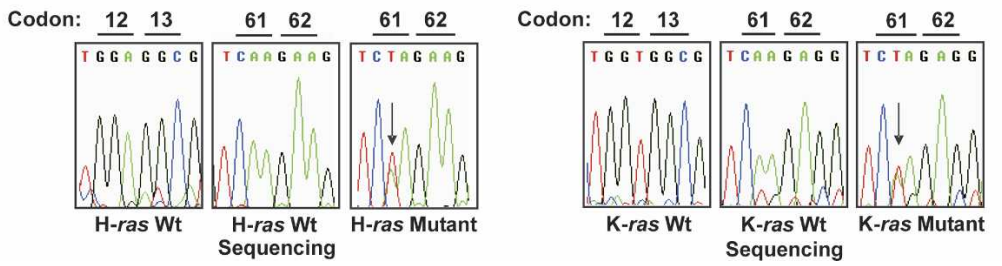

effect, transgenic mice expressing epidermal HAI-1 were generated by placing the mouse HAI-1 cDNA under the control of the bovine keratin-5 promoter and rabbit $\beta$-globin polyadenylation signals (Fig. 7A). Pronuclear injection of multiple zygotes with this transgene gave rise to just four transgenic founder mice (data not shown). Two of these four founders were capable of producing offspring and transmitted the transgene through the germline to produce two independently established transgenic lines, K5-HAI-1-A and K5-HAI-1-B. Both transgenic lines expressed the HAI- 1 transgene in the skin, as determined by HAI-1 transgene-specific RTPCR (Fig. 7B). Examination of K5-HAI-1-A mice by Northern blot analysis of skin showed low expression of the transgene (Fig. 7C). Quantitative real-time PCR analysis showed that, similarly to matriptase expression, both endogenous and transgenic HAI-1 expression were sustained at a low level in adult skin (Fig. 7D).

The abnormally low frequencies of founder fertility, germline transmission, and transgene expression level suggest that keratin-5-expressing tissues are sensitive to fluctuations in the expression levels of both matriptase and HAI- 1 .

Keratin-5-HAI-1 transgenic mice were next crossed to keratin-5-matriptase transgenic mice. The ensuing keratin-5-matriptase/keratin-5-HAI-1 double-transgenic mice and their associated keratin-5-matriptase, keratin5-HAI-1, and wild-type littermates were treated with DMBA and scored for tumor development over a 10-mo observation period (Fig. 8A). As predicted from the results presented above, tumor development was rapid in keratin-5-matriptase single-transgenic mice, with 50\% of mice presenting with tumors $17 \mathrm{wk}$ after treatment and $77 \%$ at the termination at $40 \mathrm{wk}$. Interestingly, however, the tumor susceptibility of keratin-5-matriptase/ keratin-5-HAI-1 double-transgenic mice was not signifi- cantly different from that of littermate wild-type mice or keratin-5-HAI-1 single-transgenic mice (Fig. 8A,B), showing that HAI-1 protects matriptase-expressing mice from DMBA-induced tumors. Furthermore, studies of two separate non-DMBA-treated mouse cohorts showed that all premalignant epidermal changes in keratin-5matriptase transgenic mice were completely negated by crossing to either K5-HAI-1-A (Fig. 9) or K5-HAI-1-B mice (data not shown). Keratin-5-matriptase/keratin-5HAI-1 double-transgenic mice remained outwardly indistinguishable from wild-type mice when observed for $>12$ mo (Fig. 9A), and did not display interfollicular hyperproliferation, follicular transdifferentation, dermal fibrosis, or dermal inflammation (Fig. 9B,C; data not shown). These effects were not caused by promoter competition between the keratin-5-matriptase and keratin-5HAI- 1 transgenes, as no phenotypic rescue of the keratin-5-matriptase transgenic mice was observed when the mice were crossed to two independent transgenic mouse lines that expressed irrelevant transgenes from the identical keratin-5 transgene vector (keratin-5-TVA-1 and keratin-5-TVA-2) (Orsulic et al. 2002; R. Szabo, J.S. Gutkind, and T.H. Bugge, unpubl.).

Taken together, the data show that specific inhibition of matriptase completely negates both the tumor susceptibility and all premalignant manifestations of matriptase overexpression.

\section{Discussion}

The data presented in this paper show that the type II transmembrane serine protease, matriptase, possesses a strong oncogenic potential, and that excess matriptase proteolytic activity in mouse epidermis suffices to cause cancer in the absence of other environmental or genetic challenges. One-hundred percent of transgenic mice 
Table 3. Activating ras mutations in epidermal tumors

\begin{tabular}{|c|c|c|c|c|c|}
\hline \multirow[b]{2}{*}{ Treatment/mouse } & \multirow[b]{2}{*}{ Tumor type } & \multicolumn{2}{|c|}{ H-ras } & \multicolumn{2}{|c|}{ K-ras } \\
\hline & & Codons 12-13 & Codons 59-61 & Codons 12-13 & Codons 59-61 \\
\hline \multicolumn{6}{|l|}{ DMBA + PMA } \\
\hline Wildtype-1 & Pap & wt & GGTCIAGAA & $\mathrm{wt}$ & wt \\
\hline Wildtype-2 & Pap & wt & GGTCTAGAA & wt & wt \\
\hline Wildtype-3 & SCC & wt & GGTCTAGAA & wt & wt \\
\hline Wildtype-4 & Pap & wt & wt & wt & GGTCIAGAG \\
\hline Wildtype-5 & Pap & wt & GGTCIAGAA & N/A & wt \\
\hline Wildtype-6 & Pap & wt & GGTCIAGAA & N/A & wt \\
\hline K5-Mat-B-1 & Pap & wt & GGTCIAGAA & wt & wt \\
\hline K5-Mat-B-2 & Pap & wt & GGTCIAGAA & wt & wt \\
\hline K5-Mat-B-3 & Pap & wt & GGTCIAGAA & wt & wt \\
\hline K5-Mat-B-4 & SCC & wt & $\overline{w t}$ & wt & GGTCIAGAG \\
\hline K5-Mat-B-5 & SCC & wt & wt & wt & wt \\
\hline K5-Mat-B-6 & Pap & $\mathrm{wt}$ & GGTCTAGAA & $\mathrm{wt}$ & $\mathrm{wt}$ \\
\hline \multicolumn{6}{|l|}{ DMBA } \\
\hline K5-Mat-B-7 & SCC & wt & GGTCIAGAA & N/A & wt \\
\hline K5-Mat-B-8 & SCC & wt & GGTCIAGAA & N/A & N/A \\
\hline K5-Mat-B-9 & SCC & wt & GGTCTAGAA & N/A & N/A \\
\hline K5-Mat-B-10 & SCC & wt & wt & wt & wt \\
\hline K5-Mat-B-11 & SCC & wt & GGTCIAGAA & N/A & N/A \\
\hline K5-Mat-B-12 & SCC & wt & GGTCIAGAA & N/A & N/A \\
\hline K5-Mat-B-13 & SCC & wt & wt & wt & wt \\
\hline K5-Mat-B-14 & SCC & wt & wt & wt & wt \\
\hline K5-Mat-B-15 & SCC & wt & GGTCTAGAA & N/A & wt \\
\hline K5-Mat-B-16 & Pap & wt & GGTCTAGAA & wt & $\mathrm{wt}$ \\
\hline \multicolumn{6}{|l|}{ Spontaneous tumors } \\
\hline K5-Mat-A-2 & SCC & wt & wt & $\mathrm{wt}$ & wt \\
\hline K5-Mat-A-4 & SCC & wt & wt & wt & wt \\
\hline K5-Mat-A-6 & SCC & wt & wt & wt & wt \\
\hline K5-Mat-A-7 & SCC & wt & wt & wt & wt \\
\hline K5-Mat-A-8 & $\mathrm{SCC} / \mathrm{S}$ & wt & wt & wt & wt \\
\hline K5-Mat-A-9 & $\mathrm{SCC} / \mathrm{S}$ & wt & wt & wt & wt \\
\hline K5-Mat-A-10 & SCC & wt & wt & wt & wt \\
\hline
\end{tabular}

Tumors were analyzed by PCR amplification and sequencing (Ha-ras and K-ras codons 12-13) or PCR amplification followed by sequencing and XbaI restriction digest. (Pap) Papilloma; (SCC) squamous cell carcinoma; (SCC/S) mixed spindle-shaped carcinoma; (wt) wild-type allele.

with a modest orthotopic overexpression of matriptase developed epidermal tumors in early midlife, of which the majority progressed to malignant squamous cell or spindle-shaped carcinomas. Furthermore, matriptase displayed a dramatic synergy with DMBA to cause squamous cell carcinoma in mice exposed to even an extremely low dose of the environmental genotoxin. Alternative interpretations of the presented data can largely be ruled out. Three independent data sets show that the cancer susceptibility was not caused by transgene insertion into a tumor-suppressor gene or activation of a tumor-promoting gene adjacent to the inserted transgene. First, two independently generated keratin-5-matriptase transgenic lines both displayed high epidermal tumor susceptibility, and both lines (and in addition, three other transgenic founders) presented the identical spectrum of premalignant progression. Second, in studies conducted in parallel to this under identical circumstances, we expressed numerous other genes in FVB mice using the same transgene vector without observing tu- mor development in these transgenic mice (J.S. Gutkind, K. List, J. Hobson, and T.H. Bugge, unpubl.). Third, transgenic expression of HAI-1, a specific inhibitor of matriptase, in the epidermis completely prevented the cancer susceptibility and all other phenotypic manifestations of the keratin-5-matriptase transgene, while unrelated proteins expressed from the identical transgene vector did not. We also carefully screened the matriptase cDNA used in this study for possible "activating" mutations, and found that the cDNA was identical to that of matriptase cDNA clones obtained from nontransformed tissues (K. List and T.H. Bugge, unpubl.). Furthermore, we avoided adding $\mathrm{N}$ - or C-terminal epitope tags, which could alter the biological activity of the protease. The matriptase mRNA expressed from the transgene differs from the endogenous matriptase mRNA only in the $5^{\prime}$ and $3^{\prime}$-untranslated regions (UTRs). While it is possible that the translation efficiency of the transgene-derived matriptase mRNA may be somewhat higher than the endogenous matriptase mRNA, analysis of cultured 
List et al.

Figure 7. Generation of keratin-5-HAI-1 transgenic mice. $(A)$ Schematic structure of the keratin-5-HAI-1 transgene. The bovine keratin-5 promoter (K5), rabbit $\beta$-globin exons $(\mathrm{E})$, rabbit $\beta$-globin intron $\mathrm{B}$, mouse HAI- 1 cDNA, rabbit $\beta$-globin polyadenylation signal (Poly A), and positions of primers used for mouse genotyping (a and b) and RT-PCR analysis (c and d) of transgene-specific HAI-1 mRNA are indicated. (B) Expression of the keratin-5HAI-1 in transgenic mouse skin. RT-PCR analysis of the epidermis from wild-type (lanes 1,3), littermate keratin-5-HAI-1 transgene-line-A (K5-HAI-1-A) (lane 2), and keratin-5-HAI-1 transgene-line-B (K5HAI-1-B) (lane 4), using a transgene-specific primer pair. The position of DNA fragments amplified from the HAI- 1 transgene (153 bp) and GAPDH (236 bp) are indicated with arrows. $(C)$ Northern blot analysis of total HAI-1 mRNA in the skin of wild-type and K5-HAI-1-A mice. The membranes were hybridized to HAI-1 and GAPDH cDNA fragment probes, and the signal intensity was determined by phosphor-image analysis. The ratio of HAI-1 to GAPDH signal intensity is shown. $(D)$ Quantitative real-time PCR analysis of relative endogenous HAI-1 expression in wild-type newborn skin and adult skin (4 mo) (left panel) and relative transgenic HAI-1 expression in K5-HAI-A newborn and adult skin (right panel). The matriptase expression levels were normalized to GAPDH mRNA expression. $N$ indicates the number of mice analyzed, and error bars indicate standard deviation.

transgenic and wild-type keratinocytes showed a good agreement between total matriptase mRNA and matriptase-induced gelatinolytic activity. Therefore, the total level of matriptase is unlikely to be dramatically increased in the transgenic epidermis, and would not be expected to exceed the 12 - to 600 -fold increases in matriptase expression that have been reported in human carcinomas (Oberst et al. 2001; Johnson et al. 2003; Kang et al. 2003; Hoang et al. 2004). All data, thus, converge to indicate that even a modest overexpression of matriptase in mouse epidermis suffices to cause high tumor susceptibility.
The capacity of a pericellular protease to influence malignant transformation is not without precedence. For example, $7 \%$ of aging female mice with ectopic expression of a constitutively activated mutant of the mesenchymal matrix metalloproteinase MMP-3/stromelysin-1 in the mammary epithelium were reported to develop cancer (Sternlicht et al. 1999), while loss of MMP-7/matrilysin reduced benign intestinal polyp formation in tumor-prone ApcMin mice by 60\% (Wilson et al. 1997). To our knowledge, however, matriptase is the first identified protease that causes malignant transformation with very high efficiency when expressed at increased levels
Figure 8. Increased epidermal HAI-1 prevents squamous cell carcinogenesis in keratin-5-matriptase transgenic mice. $(A)$ Kaplan-Meier analysis of epidermal tumor formation in K5-Mat-B transgenic and littermate K5-Mat-B/K5-HAI-1-A doubletransgenic, K5-HAI-1-A transgenic, and wild-type mice after a single topical application of $25 \mu \mathrm{g}$ of DMBA in acetone to the lumbar region of the dorsal back skin. $N$ indicates the number of mice initially enrolled in each study cohort. For K5Mat-B versus K5-Mat-B/K5-HAI-1 mice, $P<0.0024$; for K5-Mat-B versus wild-type mice, $P<0.0002$; for K5-Mat-B/K5-HAI1 -A versus wild-type mice, $P=$ N.S. $(\log$ rank test, two-tailed). (B) Squamous cell carcinoma (arrowhead) and papilloma (arrow) in K5-Mat-B transgenic mouse (top left panel), and tumor-free epidermis of littermate K5-Mat-B/K5-HAI-1-A double-transgenic mice (top right panel), K5-HAI-1-A transgenic mice (bottom left panel), and wild-type mice (bottom right panel). The dorsal areas were shaved prior to photography.
A

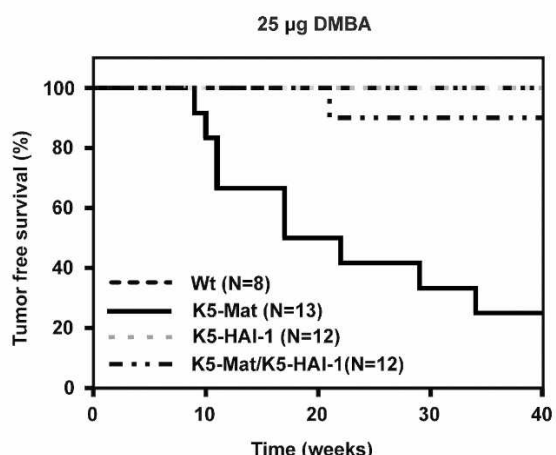

B

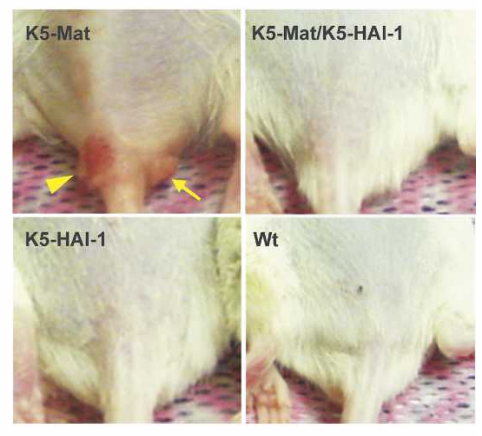


A

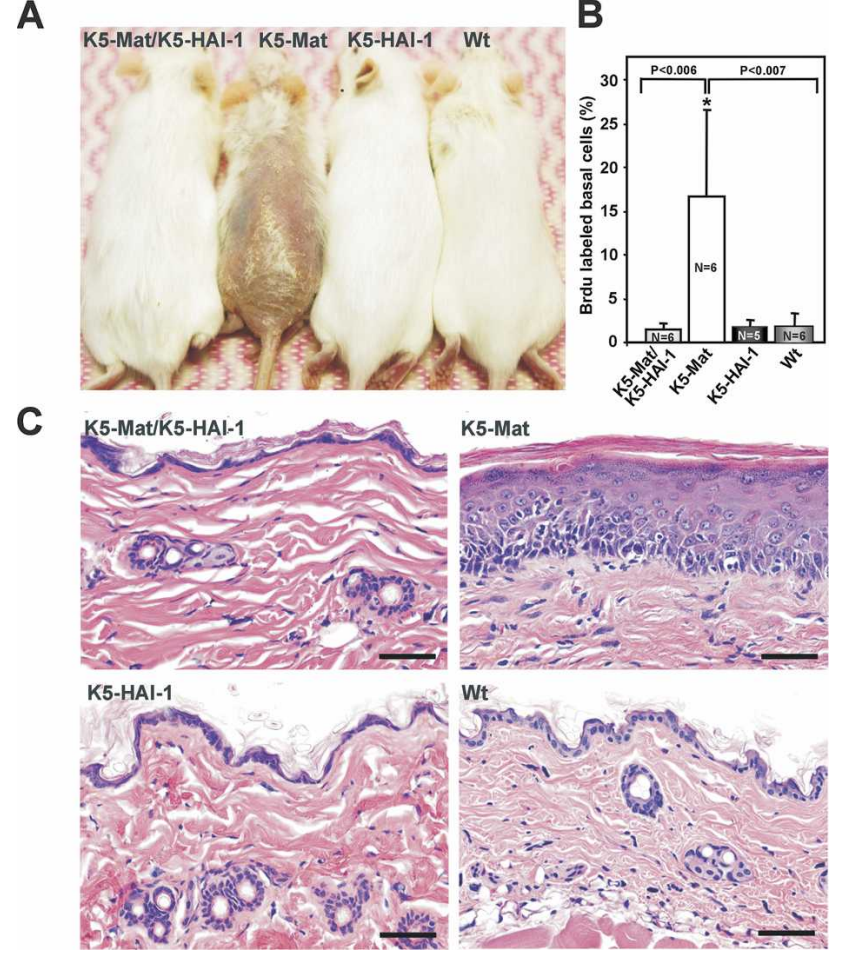

Figure 9. HAI-1 prevents premalignant progression in keratin5-matriptase transgenic mice. (A) Outward appearance of K5Mat-B transgenic and littermate K5-Mat-B/K5-HAI-1-A doubletransgenic, K5-HAI-1-A transgenic, and wild-type mice at 10 mo of age. K5-Mat-B/K5-HAI-1-A double-transgenic mice have normal outward appearance, whereas K5-Mat-B single-transgenic mice display grossly abnormal epidermis and alopecia. (B) Proliferation indices of basal keratinocytes in the epidermis of 10mo-old K5-Mat-B/K5-HAI-1-A mice (light-gray bars), K5-Mat-A mice (white bars), K5-HAI-1-A mice (black bars), and littermate wild-type mice (dark-gray bars). Mice were injected with BrdU 2 $\mathrm{h}$ before euthanization, and the fraction of BrdU incorporating basal keratinocytes was determined with BrdU antibodies. $\left({ }^{*}\right)$ $P<0.007$, Student's $t$-test, two-tailed. $(C)$ Representative examples of the histological appearance of the skin of K5-Mat-B/ K5-HAI-1-A double-transgenic mice (top left), littermate K5Mat-B mice (top right), K5-HAI-1-A mice (bottom left), and wild-type mice (bottom right) at 10 mo of age. Epidermal hyperproliferation, follicular transdifferentiation, dermal fibrosis, and dermal inflammation in K5-Mat-B single-transgenic mice, and normal skin of K5-Mat-B/K5-HAI-1-A double-transgenic mice.

in a tissue in which it is normally expressed. The findings in this paper may therefore expand the spectrum of molecules whose dysregulation can directly induce malignant transformation to also include transmembrane serine proteases. In this respect, it is noteworthy that matriptase can promote tumorigenesis via at least two distinct molecular pathways: one including the mutational activation of H-ras or K-ras (after DMBA exposure), and a second ras-independent pathway (spontaneous carcinogenesis in middle-aged mice). This implies that matriptase can drive carcinogenesis cooperatively with ras-dependent signaling, as well as with signaling pathways that are complementary to or independent of ras. This finding, when combined with the remarkably consistent overexpression of matriptase in a diverse spectrum of human carcinoma (see above), suggests a generalized role of the protease in human carcinogenesis of diverse etiology.

Matriptase is one of many proteases identified by virtue of its increased expression in human cancer (Dano et al. 1999; Matrisian 1999; Chang and Werb 2001). However, early indications suggested that the etiological contribution of the protease to carcinogenesis could be different from many tumor-associated proteases studied previously. First, matriptase is strictly expressed by the tumor cells per se, whereas most proteases that are overexpressed in cancer are expressed by the supporting nonmalignant tumor stromal cells (Dano et al. 1999; Matrisian 1999; Chang and Werb 2001). Second, matriptase is expressed by epithelial cells during all stages of malignant progression. In contrast, the onset of expression of most other tumor-cell-expressed pericellular proteases coincides with progression to malignancy (Dano et al. 1999; Matrisian 1999; Chang and Werb 2001; Hotary et al. 2003).

Dysregulated matriptase induced the full spectrum of progressive premalignant changes described previously in mouse epidermal squamous cell carcinogenesis induced by activated oncogenes, loss of tumor-suppressor genes, by carcinogen exposure, or combinations thereof. These changes included epidermal hyperplasia, dysplasia, and papilloma, activation of the tumor-promoting PI3K/Akt pathway, dermal fibrosis, hypercellularity, and inflammation. Recent attention has focused on the role of chronic inflammation as a driver of malignant progression, and several studies have demonstrated a role of inflammatory-cell-expressed pericellular proteases in inducing epithelial hyperplastic/dysplastic changes that promote tumorigenesis (Coussens and Werb 2002). In this context it should be noted, however, that we found that the matriptase-induced epidermal hyperplasia, follicular transdifferentiation, and fibrosis were unaffected by either the loss of tumor necrosis factor receptor-1dependent inflammatory pathways or severe macrophage depletion (K. List and T. Bugge, unpubl.).

Although overexpressing matriptase dramatically affected mouse epidermis, transgenic keratinocytes overexpressing matriptase were conspicuously similar to wild-type keratinocytes when cultured in vitro under a variety of conditions. Thus, matriptase overexpression led to no reproducible changes in proliferative capacity, or response to apoptosis-inducing agents or dermal fibroblast-conditioned medium (R. Szabo, V. Sriuranpong, K. List, S. Gutkind, and T.H. Bugge, unpubl.). These data suggest that matriptase supports tumor promotion via pathways that are not easily replicated ex vivo. Adding further complexity to the analysis of matriptase-induced cancer, the protease is present at very low levels in both normal and malignant epithelium ( 2 to $\sim 24$ ng of matriptase per milligram of detergent-extractable protein, respectively) (Oberst et al. 2001). Thus, the identification of the specific molecular events that underlie matrip- 
tase-induced transformation represents a considerable future challenge. These events could involve growth factor activation or inactivation, activation or shedding of growth factor receptors, cleavage of cell-cell contact proteins, cleavage of adhesion receptors, and direct modification of the extracellular matrix, which alone or in combination could create a microenvironment conducive to malignant transformation. In purified systems or cell-culture-based overexpression systems, matriptase has been previously shown to be a proficient activator of pro-urokinase, protease-activated receptor-2 (PAR-2), and hepatocyte growth factor (HGF) (Lee et al. 2000; Takeuchi et al. 2000), all of which could contribute to tumorigenesis in matriptase-dysregulated epithelium. It has recently been shown that antisense inhibition of matriptase expression in ovarian cancer cells causes a decreased invasiveness in vitro and impaired tumor growth in vivo, an effect believed to depend on the suppression of receptor-bound pro-urokinase activation (Suzuki et al. 2004). Transgenic mice expressing urokinase and its receptor under the control of the keratin-5 promoter develop plasmin-dependent skin abnormalities with epidermal thickening and sub-epidermal blisters, but no malignant lesions were reported (Zhou et al. 2000; Bolon et al. 2004). This suggests that matriptase-mediated prourokinase activation in K5-matriptase transgenic skin does not in itself suffice to cause malignant epidermal transformation. PAR-2 has been described to play a role in keratinocyte cell growth and differentiation, and in inflammatory responses (Macfarlane et al. 2001), which would be compatible with some of the effects observed by matriptase overexpression. Likewise, the activation of pro-HGF by matriptase to the multifunctional cytokine HGF has been shown to have a variety of effects on cells including stimulating growth, motility, and invasiveness via the c-met proto-oncogene receptor, and conceivably could contribute to the pleiotropic effects caused by epidermal overexpression of matriptase. It should be mentioned, however, that pro-HGF stimulates the growth of explanted matriptase-deficient epidermis as efficiently as wild-type epidermis, showing that matriptase is not essential for pro-HGF activation in mouse epidermis (R. Szabo and T.H. Bugge, unpubl.). As is the case for many other tumor-associated proteases, the elucidation of the exact molecular events by which matriptase promotes tumorigenesis may have to await the development of better protease imaging tools and in vivo substrate identification methods (McIntyre and Matrisian 2003). It is informative, however, that the persistent exposure of transgenic epidermis to the tumor promoter PMA emulated the tumorigenic effects of matriptase. This would tentatively suggest that the intracellular signaling pathways activated by PMA and matriptase could be functionally related.

The findings presented in this study may have important implications for the prevention of human cancer. Small molecule matriptase inhibitors have recently been developed, spurred by the initial epidemiological and biochemical observations regarding matriptase in cancer (Galkin et al. 2004). It now appears likely that the tar- geted application of matriptase inhibitors could substantially benefit individuals at risk for carcinogenesis due to a genetic predisposition or exposure to environmental carcinogens such as tobacco and asbestos.

\section{Materials and methods}

Mice

All experiments were performed in an Association for Assessment and Accreditation of Laboratory Animal Care International-accredited vivarium following Institutional Guidelines and standard operating procedures. Keratin-5-matriptase transgenic mice were generated by cloning the full-length $3.1-\mathrm{kb}$ mouse matriptase cDNA (GenBank AF042822) into the pBK5vector containing the $5.2-\mathrm{kb}$ bovine keratin- 5 regulatory sequences, $\beta$-globin intron 2 , and 3 '-polyadenylation sequences (Murillas et al. 1995). Keratin-5-HAI-1 transgenic mice were generated by cloning an EST (I.M.A.G.E. ID 2650110) that contains the complete full-length $2.5-\mathrm{kb}$ murine HAI- $1 \mathrm{cDNA}$ into the $\mathrm{pBK} 5$ vector. The linearized vectors were microinjected into the male pronucleus of FVB zygotes, which were implanted into pseudopregnant mice. Transgenic lines were established in an FVB background by repeated backcrossing to FVB mice (Jackson Laboratories) and maintained in the hemizygous state. The transgenic mice were genotyped by PCR and Southern blot analysis of genomic DNA extracted from tail biopsies as described previously (List et al. 2002), using the following primer pairs: Detection of the keratin-5-matriptase transgene, $5^{\prime}$-CGT GCTGGTTATTGTGCTGTCT-3' and 5'-GCTACCCATGGTT TTGGCGGTC-3'; detection of the HAI-1 transgene, 5' -CACG TGGATCCTGAGAACTTCAG-3' and $5^{\prime}$-ACCTTCACAGTG CGAGCC-3'

\section{Northern blot analysis}

Total skin RNA from snap-frozen skin samples was prepared and subjected to Northern blot analysis as described previously (List et al. 2003). The following probes were used for hybridization: Matriptase EST probe (I.M.A.G.E. ID 2609399) that contains the full-length murine Matriptase cDNA, a 553-bp fragment of the HAI-1 5'-UTR (nucleotides -112 to 443 relative to the translation initiation codon) (I.M.A.G.E. ID 2650110), and a 905-bp fragment (nucleotides 213-1117) of the mouse glyceraldehyde 3-phosphate dehydrogenase gene (GenBank M32599) (Ambion). Specific hybridization signals were quantified by phosphor-image analysis using ImageQuant software from Molecular Dynamics.

\section{RT-PCR and quantitative real-time PCR analysis}

Total skin RNA from newborn pups was amplified by reverse transcription followed by PCR amplification using Ready-to-go RT-PCR beads (Amersham Pharmacia Biotech Inc.), as recommended by the manufacturer. To specifically detect transgenic keratin-5-matriptase mRNA transcripts, first-strand cDNA synthesis was performed using a matriptase exon 1-specific primer (5'-GCTACCCATGGTTTTGGCGGTC-3'). The subsequent PCR amplification (annealing temperature $55^{\circ} \mathrm{C}$, denaturation temperature $92^{\circ} \mathrm{C}$, extension temperature $72^{\circ} \mathrm{C}, 40$ cycles) was performed with the first-strand primer in combination with a primer complementary to exon 2 of the rabbit $\beta$-globin gene (5'-CACGTGGATCCTGAGAACTTCAG-3') (GenBank V00879). The keratin-5-HAI-1 transgene was detected by RT-PCR using the rabbit $\beta$-globin gene primer in combination with the primer 
5'-ACCTTCACAGTGCGAGCC-3', complementary to the HAI-1 5'-UTR. GAPDH RT-PCR was performed with the primers: $5^{\prime}$-TTCACCACCATGGAGAAGGC- $3^{\prime}$ and $5^{\prime}$-GGCATG GACTGTGGTCATGA-3'. For quantitative real-time PCR analysis of matriptase and HAI-1 expression, first-strand cDNA synthesis was performed using Oligo(dT) primers with the RETROscript reverse transcription kit (Ambion). The Bio-Rad iCycler, Gene Expression Analysis software, and IQ SYBR Green Supermix (Bio-Rad Laboratories) was used for real-time RT-PCR in accordance with the manufacturer's directions, using the following primers: total matriptase, $5^{\prime}$-AGATCTTTC TGGATGCGTATGAGA-3' and 5'-GGACTTCATTGTACAG CAGCTTCA-3'; transgenic matriptase, 5'-GAACTTCAGGC TCCTGGGCAA-3' and 5'-CTCCGGGCAGCCGTCTACCA TG-3'; total HAI-1, 5' -CACCACTCAGAACTGCAACC-3' and 5'-GAAGTTCTGCTCGTACAGGC-3' ; transgenic HAI-1, 5'-GA ACTTCAGGCTCCTGGGCAA-3' and 5'-TTGTGACCGGAA CGCGTGGG-3' (annealing temperature $60^{\circ} \mathrm{C}$, denaturation temperature $95^{\circ} \mathrm{C}$, extension temperature $72^{\circ} \mathrm{C}$, 40 cycles). Matriptase and HAI-1 expression levels were normalized against GAPDH levels in each sample and amplified with the primers 5'-GTGAAGCAGGCATCTGAGG-3' and 5'-CATCGAAGGT GGAAGAGTGG-3'.

\section{In situ hybridization}

The full-length matriptase cDNA was used as a template to generate two nonoverlapping PCR fragments for transcription of antisense probes, f118 (bp 1000-1490) and f120 (bp 15002000), which were flanked by a $5^{\prime}$-linker sequence encoding the T7 RNA polymerase-binding site (Schnack Nielsen et al. 2002) underlined in the following primer sequences: f118 up, $5^{\prime}$-TGT CACGCTGATAACCAATA-3'; down T7(1), 5'-AATAATAC GACTCACTATAGGGAGGTCTGCCCAGCCGTCGCAGC-3'; and f120 up, 5'-ATAGTGATGAGCGTTACTGC-3'; down T7(2), 5' - AATAATACGACTCACTATAGGGAGGATGAGCGAGG CCCCACACA-3'. Similarly, two nonoverlapping PCR fragments [f117 down, 5'-GTCTGCCCAGCCGTCGCAGC-3'; up T3(1), 5'-ATTAACCCTCACTAAAGGGAGATGTCACGCTG ATAACCAATA-3'; and f119 down, 5'-GATGAGCGAGGCC CCACACA-3'; upT3(2), 5'-ATTAACCCTCACTAAAGGGA GAATAGTGATGAGCGTTACTGC-3'] for transcription of the complementary sense probes were generated. These PCR templates were flanked by a 5 '-linker sequence encoding the T3 RNA polymerase-binding site (underlined). Antisense and sense riboprobes were labeled with ${ }^{35} \mathrm{~S}$-UTP (NEN) by in vitro transcription using T7 and T3 RNA polymerases (Roche) and $\sim 1 \mu \mathrm{g}$ of template. The DNA template was digested with DNase (Promega), unincorporated ${ }^{35}$ S-UTP and DNA were removed by column chromatography using S-200HR microspin columns (Amersham Pharmacia Biotech Inc.), and the ${ }^{35} \mathrm{~S}$ activity was adjusted for every probe by dilution to $500,000 \mathrm{cpm} / \mu \mathrm{L}$. In situ hybridization was performed essentially as described previously

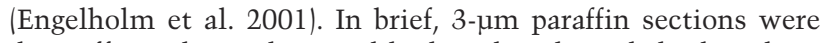
deparaffinized in xylene and hydrated with graded ethanol solutions. Sections were incubated at $99^{\circ} \mathrm{C}$ for $2 \mathrm{~min}$ in TEG buffer (10 mM Tris at $\mathrm{pH} 9.0,0.5 \mathrm{mmol} / \mathrm{L}$ EGTA) using a T/T Micromed microwave processor (Milestone). After an additional $20 \mathrm{~min}$ at room temperature, the sections were dehydrated with graded ethanol and the ${ }^{35}$ S-labeled probes $\left(2 \times 10^{6} \mathrm{cpm}\right.$ in $20 \mu \mathrm{L}$ of hybridization mixture per slide) were incubated overnight at $55^{\circ} \mathrm{C}$ in a humidified chamber. Sections were washed in Hellendahl chambers with SSC buffers containing $0.1 \%$ SDS and 10 $\mathrm{mM} \mathrm{DTT}$ at $150 \mathrm{rpm}$ at $55^{\circ} \mathrm{C}$ using a Bühler incubation shaker (Johanna Otto $\mathrm{GmbH}$ ) for $10 \mathrm{~min}$ in $2 \times \mathrm{SSC}, 10 \mathrm{~min}$ in $0.5 \times$ SSC, and $10 \mathrm{~min}$ in $0.2 \times$ SSC. Sections were then RNase A-treated for
$10 \mathrm{~min}$ to remove nonspecifically bound riboprobe. Subsequent washes were performed in $0.2 \times$ SSC as specified above. Sections were dehydrated and soaked in an autoradiographic emulsion, exposed for 10-14 d, developed, and counterstained with hematoxylin and eosin.

\section{Chemical carcinogenesis}

Two-stage carcinogenesis: The dorsal skin of 6- to 8-wk-old mice was shaved and treated $2 \mathrm{~d}$ later with a single topical application of $25 \mu \mathrm{g}$ of 7,12-dimethylbenzanthracene (DMBA) in $200 \mu \mathrm{L}$ of acetone (Sigma), followed 2 wk later by biweekly applications of $12 \mu \mathrm{g}$ of phorbol 12-myristate 13-acetate (PMA; Sigma) for $20 \mathrm{wk}$.

One-stage carcinogenesis: The shaved dorsal area of mice was treated with a single application of 2,25 , or $100 \mu \mathrm{g}$ of DMBA in $200 \mu \mathrm{L}$ of acetone. The tumor incidence in the carcinogen-treated mice was monitored weekly. Mice with ulcerating tumors or tumors reaching a diameter of $>1 \mathrm{~cm}$ were euthanized prior to the termination of the study. Tumors and organs were either snap-frozen in liquid nitrogen for further DNA and RNA analyses, or fixed in $4 \%$ paraformaldehyde and processed for histology.

Histological assessment and immunohistochemical analysis of epidermis and tumors

Skin and tumor tissues were fixed for $24 \mathrm{~h}$ in $4 \%$ paraformaldehyde in PBS, embedded into paraffin, sectioned, and stained with hematoxylin and eosin or Masson's trichrome prior to histopathological assessment. Immunohistochemical analysis was performed as described previously (List et al. 2002). Antibodies recognizing keratin-1, keratin-6, keratin-10, filaggrin, loricrin (Covance), Phospho-PDK1, Phospho-Akt (Cell Signaling Technology), vimentin (Zymed), cytokeratin (Dako), F4/80 (Caltag Laboratories), and E-cadherin (BD Biosciences) were used for staining. Epithelial cell proliferation was visualized by intraperitoneal injection of $100 \mu \mathrm{g} / \mathrm{g}$ of BrdU $2 \mathrm{~h}$ prior to euthanasia. BrdU incorporation was detected with a mouse anti-BrdU antibody. Bound antibodies were visualized with the Vectastain $\mathrm{ABC}$ peroxidase kit as recommended by the manufacturer (Vector Laboratories). Mast cells were visualized by toluidine blue staining $[0.05 \%(\mathrm{w} / \mathrm{v})]$ and eosin counterstaining.

\section{Keratinocyte culture and in vitro proliferation assays}

Primary keratinocytes from keratin-5-matriptase transgenic mice and wild-type littermate controls were isolated from newborn skin as described (Netzel-Arnett et al. 2002). The keratinocytes were grown in keratinocyte serum-free medium supplemented with epidermal growth factor and bovine pituitary extract (Invitrogen) and $0.08 \mathrm{mM} \mathrm{CaCl}_{2}$. To determine in vitro proliferation rate, keratinocytes were grown in culture for $3 \mathrm{~d}$ and trypsinized, and living cells were visualized with Trypan Blue and counted. Ten-thousand cells were reseeded onto sixwell plates and counted every $24 \mathrm{~h}$.

\section{Matriptase gelatin zymography}

Gelatin zymography for matriptase was performed as described (Jin et al. 2005). Briefly, serum-free medium conditioned for $4 \mathrm{~d}$ by keratinocytes grown to confluency on standard tissue culture plates as described above was collected, centrifuged to remove cell debris, and dialyzed against distilled water overnight at $4^{\circ} \mathrm{C}$. The dialyzed samples were lyophilized, and the dried protein powder was dissolved in a $1 / 100$ volume of the initial condi- 
tioned medium in $20 \mathrm{mM}$ Tris- $\mathrm{HCl}(\mathrm{pH} 7.5)$. Concentrated medium from keratin-5-matriptase transgenic and wild-type primary keratinocyte cultures were separated by SDS-PAGE under nonreducing conditions, and the gels (containing $0.1 \%$ gelatin) were subsequently incubated in renaturation buffer $150 \mathrm{mM}$ Tris- $\mathrm{HCl}$ at $\mathrm{pH} 7.5,100 \mathrm{mM} \mathrm{NaCl}$, and $2.5 \%$ Triton $\mathrm{X}-100$ ) for $1.5 \mathrm{~h}$ followed by $30 \mathrm{~min}$ in EDTA buffer $(50 \mathrm{mM}$ Tris- $\mathrm{HCl}$ at $\mathrm{pH} 7.5,0.5 \mathrm{mM}$ EDTA) to eliminate matrix metalloproteinase activities as described (Jin et al. 2005). The gels were incubated at $37^{\circ} \mathrm{C}$ for $16 \mathrm{~h}$ in developing buffer $(50 \mathrm{mM}$ Tris- $\mathrm{HCl}$ at $\mathrm{pH} 7.5$ with $5 \mathrm{mM} \mathrm{CaCl}_{2}$ ), and stained with Coomassie Brilliant Blue to detect zones of gelatinolysis. For serine protease inhibition, lysates were preincubated with $1 \mathrm{mM}$ phenylmethyl sulfonyl fluoride for $1 \mathrm{~h}$ at room temperature before SDS-PAGE, and the inhibitor $(1 \mathrm{mM})$ was furthermore added to the renaturation and developing buffers. Semiquantitative analysis of gelatinolytic activity was performed using Scion Image Beta software (Scion Corporation).

\section{DNA extraction}

Tumors were collected at euthanization, snap-frozen, and ground to a powder in liquid nitrogen. For DNA extraction, $\sim 50$ mg of tumor powder was digested overnight with $2 \mathrm{mg} / \mathrm{mL}$ Proteinase $\mathrm{K}$ in $20 \mathrm{mM}$ Tris- $\mathrm{HCl}(\mathrm{pH} 8.5), 200 \mathrm{mM} \mathrm{NaCl}, 5 \mathrm{mM}$ EDTA, and $0.2 \%$ SDS, followed by phenol-chloroform extraction and ethanol precipitation.

$H$-ras and $K$-ras mutation analysis

Genomic DNA was isolated from frozen or paraffin-embedded tumor samples. Mutations in codon 61 of $\mathrm{H}$-ras and K-ras were analyzed by PCR amplification of a 371-bp H-ras exon 2 fragment and a 233-bp K-ras exon 2 fragment, followed by XbaI restriction digest analysis as well as direct sequence analysis. Mutations in codons 12 and 13 were analyzed by PCR amplification of a 371-bp H-ras exon 1 fragment and a 237-bp K-ras exon 1 fragment, followed by direct sequencing of the amplified products. The following primers were used: mouse H-ras exon 1, 5'-GCAGCCGCTGTAGAAGCTATGA-3' and 5'-GTAGGCA GAGCTCACCTCTATA-3'; mouse H-ras exon 2, 5'-CATGAC TGTGTCCAGGACATTC- ${ }^{\prime}$ ' and $5^{\prime}$-TAGGCTGGTTCTGTG GATTCTC-3'; K-ras first coding exon, 5'-TACACACAAAG GTGAGTGTTAAAATATTGATAA-3' and 5'-AGAGCAGCG TTACCTCTATC-3'; K-ras second coding exon, 5'-AAGATG CACTGTAATAATCCAGAC-3' and 5'-ATTCAACTTAAAC CCACCTATA-3'. Amplification was performed for 30 cycles of $60 \mathrm{sec}$ at $94^{\circ} \mathrm{C}, 60 \mathrm{sec}$ at $55^{\circ} \mathrm{C}$, and $60 \mathrm{sec}$ at $72^{\circ} \mathrm{C}$. Amplification products were purified with a PCR purification kit (QIAGEN) and sequenced with an ABI Prism 3100 Genetic Analyzer (Applied Biosystems).

\section{Acknowledgments}

We thank Drs. Stuart Yuspa and Ulrike Lichti for boundless help and support; Drs. Ashok B. Kulkarni, Taduru Sreenath, and Andrew Cho for generation of transgenic mice; and Charlotte Lønborg for excellent technical assistance. We also thank Drs. Robert Angerer, Mary Jo Danton, and Julie Segre for critically reading this manuscript, and Dr. Pamonwat Amornphimoltham for advice on real-time PCR analysis. The full-length mouse matriptase cDNA was generously provided by Dr. Moon Gyo Kim.

\section{References}

Amornphimoltham, P., Sriuranpong, V., Patel, V., Benavides, F., Conti, C.J., Sauk, J., Sausville, E.A., Molinolo, A.A., and
Gutkind, J.S. 2004. Persistent activation of the Akt pathway in head and neck squamous cell carcinoma: A potential target for UCN-01. Clin. Cancer Res. 10: 4029-4037.

Balmain, A. 1985. Transforming ras oncogenes and multistage carcinogenesis. Br. J. Cancer 51: 1-7.

Balmain, A. and Pragnell, I.B. 1983. Mouse skin carcinomas induced in vivo by chemical carcinogens have a transforming Harvey-ras oncogene. Nature 303: 72-74.

Benaud, C.M., Oberst, M., Dickson, R.B., and Lin, C.Y. 2002. Deregulated activation of matriptase in breast cancer cells. Clin. Exp. Metastasis 19: 639-649.

Bhatt, A.S., Takeuchi, T., Ylstra, B., Ginzinger, D., Albertson, D., Shuman, M.A., and Craik, C.S. 2003. Quantitation of membrane type serine protease 1 (MT-SP1) in transformed and normal cells. Biol. Chem. 384: 257-266.

Bolon, I., Zhou, H.M., Charron, Y., Wohlwend, A., and Vassalli, J.D. 2004. Plasminogen mediates the pathological effects of urokinase-type plasminogen activator overexpression. Am. I. Pathol. 164: 2299-2304.

Chang, C. and Werb, Z. 2001. The many faces of metalloproteases: Cell growth, invasion, angiogenesis and metastasis. Trends. Cell Biol. 11: S37-S43.

Cho, E.G, Kim, M.G., Kim, C., Kim, S.R., Seong, I.S., Chung, C., Schwartz, R.H., and Park, D. 2001. N-terminal processing is essential for release of epithin, a mouse type II membrane serine protease. J. Biol. Chem. 276: 44581-44589.

Coussens, L.M. and Werb, Z. 2002. Inflammation and cancer. Nature 420: 860-867.

Dano, K., Romer, J., Nielsen, B.S., Bjorn, S., Pyke, C., Rygaard, J., and Lund, L.R. 1999. Cancer invasion and tissue remodeling-Cooperation of protease systems and cell types. Apmis 107: 120-127.

Engelholm, L.H., Nielsen, B.S., Netzel-Arnett, S., Solberg, H., Chen, X.D., Lopez Garcia, J.M., Lopez-Otin, C., Young, M.F., Birkedal-Hansen, H., Dano, K., et al. 2001. The urokinase plasminogen activator receptor-associated protein/endo180 is coexpressed with its interaction partners urokinase plasminogen activator receptor and matrix metalloprotease-13 during osteogenesis. Lab. Invest. 81: 1403-1414.

Galkin, A.V., Mullen, L., Fox, W.D., Brown, J., Duncan, D., Moreno, O., Madison, E.L., and Agus, D.B. 2004. CVS-3983, a selective matriptase inhibitor, suppresses the growth of androgen independent prostate tumor xenografts. Prostate 61: 228 .

Hennings, H., Glick, A.B., Lowry, D.T., Krsmanovic, L.S., Sly, L.M., and Yuspa, S.H. 1993. FVB/N mice: An inbred strain sensitive to the chemical induction of squamous cell carcinomas in the skin. Carcinogenesis 14: 2353-2358.

Hoang, C.D., D'Cunha, J., Kratzke, M.G., Casmey, C.E., Frizelle, S.P., Maddaus, M.A., and Kratzke, R.A. 2004. Gene expression profiling identifies matriptase overexpression in malignant mesothelioma. Chest 125: 1843-1852.

Hooper, J.D., Campagnolo, L., Goodarzi, G., Truong, T.N., Stuhlmann, H., and Quigley, J.P. 2003. Mouse matriptase-2: Identification, characterization and comparative mRNA expression analysis with mouse hepsin in adult and embryonic tissues. Biochem. J. 373: 689-702.

Hotary, K.B., Allen, E.D., Brooks, P.C., Datta, N.S., Long, M.W., and Weiss, S.J. 2003. Membrane type I matrix metalloproteinase usurps tumor growth control imposed by the threedimensional extracellular matrix. Cell 114: 33-45.

Ise, K., Nakamura, K., Nakao, K., Shimizu, S., Harada, H., Ichise, T., Miyoshi, J., Gondo, Y., Ishikawa, T., Aiba, A., et al. 2000. Targeted deletion of the H-ras gene decreases tumor formation in mouse skin carcinogenesis. Oncogene 19: $2951-2956$. 
Jin, X., Hirosaki, T., Lin, C.Y., Dickson, R.B., Higashi, S., Kitamura, H., and Miyazaki, K. 2005. Production of soluble matriptase by human cancer cell lines and cell surface activation of its zymogen by trypsin. J. Cell Biochem. 95: 632-647.

Johnson, M.D., Oberst, M.D., Lin, C.Y., and Dickson, R.B. 2003. Possible role of matriptase in the diagnosis of ovarian cancer. Expert. Rev. Mol. Diagn. 3: 331-338.

Kang, J.Y., Dolled-Filhart, M., Ocal, I.T., Singh, B., Lin, C.Y., Dickson, R.B., Rimm, D.L., and Camp, R.L. 2003. Tissue microarray analysis of hepatocyte growth factor/Met pathway components reveals a role for Met, matriptase, and hepatocyte growth factor activator inhibitor 1 in the progression of node-negative breast cancer. Cancer Res. 63: 11011105.

Kim, M.G., Chen, C., Lyu, M.S., Cho, E.G., Park, D., Kozak, C., and Schwartz, R.H. 1999. Cloning and chromosomal mapping of a gene isolated from thymic stromal cells encoding a new mouse type II membrane serine protease, epithin, containing four LDL receptor modules and two CUB domains. Immunogenetics 49: 420-428.

Lee, S.L., Dickson, R.B., and Lin, C.Y. 2000. Activation of hepatocyte growth factor and urokinase/plasminogen activator by matriptase, an epithelial membrane serine protease. J. Biol. Chem. 275: 36720-36725.

Lin, C.Y., Anders, J., Johnson, M., Sang, Q.A., and Dickson, R.B. 1999. Molecular cloning of cDNA for matriptase, a matrixdegrading serine protease with trypsin-like activity. J. Biol. Chem. 274: 18231-18236.

List, K., Haudenschild, C.C., Szabo, R., Chen, W., Wahl, S.M., Swaim, W., Engelholm, L.H., Behrendt, N., and Bugge, T.H. 2002. Matriptase/MT-SP1 is required for postnatal survival, epidermal barrier function, hair follicle development, and thymic homeostasis. Oncogene 21: 3765-3779.

List, K., Szabo, R., Wertz, P.W., Segre, J., Haudenschild, C.C., Kim, S.Y., and Bugge, T.H. 2003. Loss of proteolytically processed filaggrin caused by epidermal deletion of Matriptase/ MT-SP1. J. Cell Biol. 163: 901-910.

Macfarlane, S.R., Seatter, M.J., Kanke, T., Hunter, G.D., and Plevin, R. 2001. Proteinase-activated receptors. Pharmacol. Rev. 53: 245-282.

Matrisian, L.M. 1999. Cancer biology: Extracellular proteinases in malignancy. Curr. Biol. 9: 776-778.

McIntyre, J.O. and Matrisian, L.M. 2003. Molecular imaging of proteolytic activity in cancer. I. Cell Biochem. 90: 10871097.

Murillas, R., Larcher, F., Conti, C.J., Santos, M., Ullrich, A., and Jorcano, J.L. 1995. Expression of a dominant negative mutant of epidermal growth factor receptor in the epidermis of transgenic mice elicits striking alterations in hair follicle development and skin structure. EMBO J. 14: 5216-5223.

Netzel-Arnett, S., Mitola, D.J., Yamada, S.S., Chrysovergis, K., Holmbeck, K., Birkedal-Hansen, H., and Bugge, T.H. 2002. Collagen dissolution by keratinocytes requires cell surface plasminogen activation and matrix metalloproteinase activity. J. Biol. Chem. 277: 45154-45161.

Netzel-Arnett, S., Hooper, J.D., Szabo, R., Madison, E.L., Quigley, J.P., Bugge, T.H., and Antalis, T.M. 2003. Membrane anchored serine proteases: A rapidly expanding group of cell surface proteolytic enzymes with potential roles in cancer. Cancer Metastasis Rev. 22: 237-258.

Oberst, M., Anders, J., Xie, B., Singh, B., Ossandon, M., Johnson, M., Dickson, R.B., and Lin, C.Y. 2001. Matriptase and HAI-1 are expressed by normal and malignant epithelial cells in vitro and in vivo. Am. J. Pathol. 158: 1301-1311.

Oberst, M.D., Johnson, M.D., Dickson, R.B., Lin, C.Y., Singh, B., Stewart, M., Williams, A., al-Nafussi, A., Smyth, J.F., Gabra,
H., et al. 2002. Expression of the serine protease matriptase and its inhibitor HAI-1 in epithelial ovarian cancer: Correlation with clinical outcome and tumor clinicopathological parameters. Clin. Cancer. Res. 8: 1101-1107.

Orsulic, S., Li, Y., Soslow, R.A., Vitale-Cross, L.A., Gutkind, J.S., and Varmus, H.E. 2002. Induction of ovarian cancer by defined multiple genetic changes in a mouse model system. Cancer Cell 1: 53-62.

Parr, C. and Jiang, W.G. 2001. Expression of hepatocyte growth factor/scatter factor, its activator, inhibitors and the c-Met receptor in human cancer cells. Int. J. Oncol. 19: 857-863.

Quintanilla, M., Brown, K., Ramsden, M., and Balmain, A. 1986. Carcinogen-specific mutation and amplification of Ha-ras during mouse skin carcinogenesis. Nature 322: 78-80.

Ramirez, A., Bravo, A., Jorcano, J.L., and Vidal, M. 1994. Sequences $5^{\prime}$ of the bovine keratin 5 gene direct tissue- and cell-type-specific expression of a lacZ gene in the adult and during development. Differentiation 58: 53-64.

Santin, A.D., Cane, S., Bellone, S., Bignotti, E., Palmieri, M., De Las Casas, L.E., Anfossi, S., Roman, J.J., O'Brien, T., and Pecorelli, S. 2003. The novel serine protease tumor-associated differentially expressed gene-15 (matriptase/MT-SP1) is highly overexpressed in cervical carcinoma. Cancer 98: $1898-1904$

Santin, A.D., Zhan, F., Bellone, S., Palmieri, M., Cane, S., Bignotti, E., Anfossi, S., Gokden, M., Dunn, D., Roman, J.J., et al. 2004. Gene expression profiles in primary ovarian serous papillary tumors and normal ovarian epithelium: Identification of candidate molecular markers for ovarian cancer diagnosis and therapy. Int. J. Cancer 112: 14-25.

Schnack Nielsen, B., Rank, F., Engelholm, L.H., Holm, A., Dano, K., and Behrendt, N. 2002. Urokinase receptor-associated protein (UPARAP) is expressed in connection with malignant as well as benign lesions of the human breast and occurs in specific populations of stromal cells. Int. J. Cancer 98: 656-664.

Segrelles, C., Ruiz, S., Perez, P., Murga, C., Santos, M., Budunova, I.V., Martinez, J., Larcher, F., Slaga, T.J., Gutkind, J.S., et al. 2002. Functional roles of Akt signaling in mouse skin tumorigenesis. Oncogene 21: 53-64.

Sternlicht, M.D., Lochter, A., Sympson, C.J., Huey, B., Rougier, J.P., Gray, J.W., Pinkel, D., Bissell, M.J., and Werb, Z. 1999. The stromal proteinase MMP3/stromelysin-1 promotes mammary carcinogenesis. Cell 98: 137-146.

Suzuki, M., Kobayashi, H., Kanayama, N., Saga, Y., Suzuki, M., Lin, C.Y., Dickson, R.B., and Terao, T. 2004. Inhibition of tumor invasion by genomic down-regulation of matriptase through suppression of activation of receptor-bound prourokinase. J. Biol. Chem. 279: 14899-14908.

Szabo, R., Netzel-Arnett, S., Hobson, J.P., Antalis, T.M., and Bugge, T.H. 2005. Matriptase-3 is a novel phylogenetically preserved membrane-anchored serine protease with broad serpin reactivity. Biochem. J. 390: 231-240.

Takeuchi, T., Shuman, M.A., and Craik, C.S. 1999. Reverse biochemistry: Use of macromolecular protease inhibitors to dissect complex biological processes and identify a membranetype serine protease in epithelial cancer and normal tissue. Proc. Natl. Acad. Sci. 96: 11054-11061.

Takeuchi, T., Harris, J.L., Huang, W., Yan, K.W., Coughlin, S.R., and Craik, C.S. 2000. Cellular localization of membranetype serine protease 1 and identification of protease-activated receptor- 2 and single-chain urokinase-type plasminogen activator as substrates. J. Biol. Chem. 275: 26333-26342.

Tanimoto, H., Underwood, L.J., Wang, Y., Shigemasa, K., Parmley, T.H., and $\mathrm{O}^{\prime}$ Brien, T.J. 2001. Ovarian tumor cells express a transmembrane serine protease: A potential candidate for 
List et al.

early diagnosis and therapeutic intervention. Tumour Biol. 22: 104-114.

Velasco, G., Cal, S., Quesada, V., Sanchez, L.M., and LopezOtin, C. 2002. Matriptase-2, a membrane-bound mosaic serine proteinase predominantly expressed in human liver and showing degrading activity against extracellular matrix proteins. J. Biol. Chem. 277: 37637-37646.

Vivanco, I. and Sawyers, C.L. 2002. The phosphatidylinositol 3-Kinase AKT pathway in human cancer. Nat. Rev. Cancer 2: 489-501.

Wilson, C.L., Heppner, K.J., Labosky, P.A., Hogan, B.L., and Matrisian, L.M. 1997. Intestinal tumorigenesis is suppressed in mice lacking the metalloproteinase matrilysin. Proc. Natl. Acad. Sci. 94: 1402-1407.

Yuspa, S.H. 1998. The pathogenesis of squamous cell cancer: Lessons learned from studies of skin carcinogenesis. J. Dermatol. Sci. 17: 1-7.

Zhou, H.M., Nichols, A., Meda, P., and Vassalli, J.D. 2000. Urokinase-type plasminogen activator and its receptor synergize to promote pathogenic proteolysis. EMBO J. 19: 48174826. 


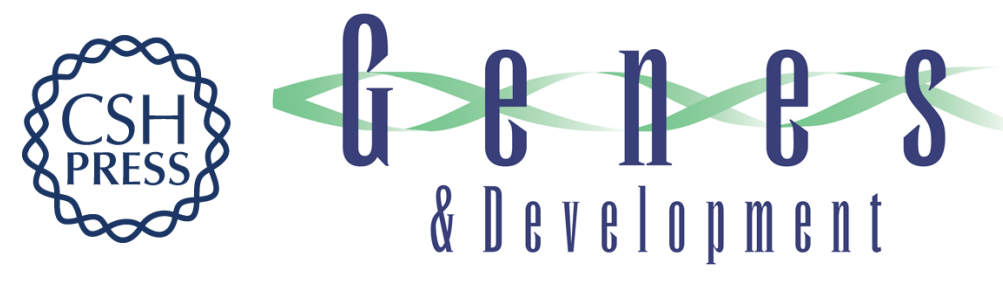

\section{Deregulated matriptase causes ras-independent multistage carcinogenesis and promotes ras-mediated malignant transformation}

Karin List, Roman Szabo, Alfredo Molinolo, et al.

Genes Dev. 2005, 19:

Access the most recent version at doi:10.1101/gad.1300705

References This article cites 51 articles, 15 of which can be accessed free at: http://genesdev.cshlp.org/content/19/16/1934.full.html\#ref-list-1

License

Email Alerting

Receive free email alerts when new articles cite this article - sign up in the box at the top Service right corner of the article or click here.

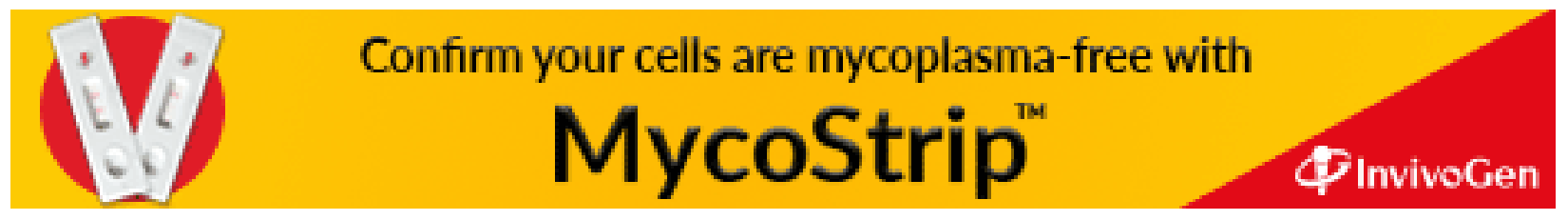

